\title{
Long term changes in the ecosystem in the northern South China Sea during 1976-2004
}

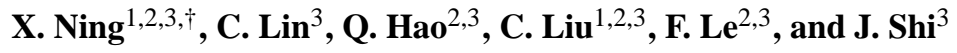 \\ ${ }^{1}$ State Key Lab of Satellite Ocean Environment Dynamics, China \\ ${ }^{2}$ SOA Key Lab of Marine Ecosystems and Biogeochemistry, China \\ ${ }^{3}$ Second Institute of Oceanography (SIO), State Oceanic Administration (SOA), Hangzhou, Zhejiang, 310012, China \\ $\dagger$ deceased
}

Received: 22 July 2008 - Published in Biogeosciences Discuss.: 12 September 2008

Revised: 26 May 2009 - Accepted: 6 October 2009 - Published: 26 October 2009

\begin{abstract}
Physical and chemical oceanographic data were obtained by seasonal monitoring along a transect (Transect N) in the northern South China Sea (nSCS) during 19762004. Fluctuations of DIN (dissolved inorganic nitrogen), seawater temperature (SST and $T_{a v}$ - average temperature of the water column), N:P ratio and salinity ( $S_{a v}$ and $S_{200}$ - salinity at the $200 \mathrm{~m}$ layer) exhibited an increasing trend, while those of $T_{200}, \mathrm{DO}, \mathrm{P}, \mathrm{Si}, \mathrm{Si} \mathrm{N}$ and SSS exhibited a decreasing trend. The annual rates of change in DIN, DO, $\mathrm{T}$ and $\mathrm{S}$ revealed pronounced changes, and the climate trend coefficients, which was defined as the correlation coefficient between the time series of an environmental parameter and the nature number (namely $1,2,3, \ldots . . n$ ), were 0.38 to 0.89 and significant $(p \leq 0.01$ to 0.05$)$. Our results also showed that the ecosystem has obviously been influenced by the positive trends of both SST and DIN, and negative trends of both DO and P. For example, before 1997, DIN concentrations in the upper layer were very low and N:P ratios were less than half of the Redfield ratio of 16 , indicating potential $\mathrm{N}$ limitation. However after 1997, all Si:P ratios were $>22$ and the $\mathrm{N}_{a v}: \mathrm{P}_{a v}$ was close to the Redfield ratio, indicating potential $\mathrm{P}$ limitation, and therefore $\mathrm{N}$ limitation has been reduced after 1997.

Ecological investigation shows that there have been some obvious responses of the ecosystems to the long-term environmental changes in the nSCS. Chlorophyll- $a$ concentration, primary production, phytoplankton abundance, benthic biomass, cephalopod catch and demersal trawl catch have increased. But phosphorus depletion in upper layer may be related to the shift in the dominant species from diatoms to dinoflagellates and cyanophytes. The ecosystem response was
\end{abstract}

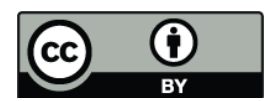

Correspondence to: F. Le (le_ff@126.com) induced by not only anthropogenic activities, but also global climate change, e.g. ENSO. The effects of climate change on the nSCS were mainly through changes in the monsoon winds, and physical-biological oceanography coupling processes.

In this study physical-chemical parameters were systemic maintained, but the contemporaneous biological data were collected from various sources. Regional response to global climate change is clearly a complicated issue, which is far from well understood. This study was made an attempt to tackle this important issue. For the aim these data were valuable.

\section{Introduction}

The South China Sea (SCS) is the largest semi-enclosed marginal sea in Southeast Asia with an area of about $3.5 \times 10^{6} \mathrm{~km}^{2}$. Our study area is the northern SCS (nSCS), bounded by the mainland of China on the north and northwest sides, Taiwan Strait on the northeast, Taiwan Island and Bashi Strait on the east side, and the Hainan Island on the west side. The nSCS is connected to the East China Sea through Taiwan Strait, and it is connected to the open ocean through Luzon Strait, where a deep sill $(>2000 \mathrm{~m})$ allows effective water exchange with the western Pacific. The topography of the area is characterized by the incline from the coast of mainland China towards the southeast, with a gradient from the coastal zone $(<50 \mathrm{~m})$, continental shelf $(<200 \mathrm{~m})$, the slope and open sea $(>200 \mathrm{~m})$, to the deep sea (>3000 m) (Fig. 1).

The runoff from 29 rivers, with different sized input into the nSCS with total drainage area of $5.5 \times 10^{5} \mathrm{~km}^{2}$, and an annual fresh water discharge of $3.8 \times 10^{11} \mathrm{~m}^{3}$ (Han et

Published by Copernicus Publications on behalf of the European Geosciences Union. 
al., 1998). Among them, the Pearl River is the largest with a drainage area of $4.3 \times 10^{5} \mathrm{~km}^{2}$ and a discharge of $3.3 \times 10^{11} \mathrm{~m}^{3} \mathrm{y}^{-1}$ (Han et al., 1998). It carries a large quantity of suspended solids $\left(8.3 \times 10^{7} \mathrm{ty}^{-1}\right.$, Han et al., 1998) and dissolved nutrients $\left(\mathrm{N}=8.6 \times 10^{4} \mathrm{ty}^{-1} ; \mathrm{P}=1.2 \times 10^{4} \mathrm{ty}^{-1}\right.$; $\mathrm{Si}=184.3 \times 10^{4} \mathrm{ty}^{-1}$, before 1998, Wang and Peng, 1996; and $\mathrm{N}=19.14 \times 10^{4} \mathrm{ty}^{-1}, \mathrm{P}=0.8 \times 10^{4} \mathrm{ty}^{-1}$ after 1998, SOAC, 2000, 2001, 2002, 2003, 2004) into the nSCS. The Pearl River plume extends offshore to cover a large area of the nSCS (Yin et al., 2001). During the dry season in winter, the river plumes extend westward along the coast of Guangdong. Due to the strong northeast monsoon; during the flood season in summer, the river plume extends well into the nSCS, and its southeastward and southward tongue can reach up to $17^{\circ} 00^{\prime} \mathrm{N}, 112^{\circ} \mathrm{E}$, about 5 degrees, in latitude, away from the river mouth (Cai et al., 2007; Xue et al., 2001a, b).

The meteorological forcing over the nSCS is dominated by the East Asian Monsoon (Sadler et al., 1985). The upper ocean circulation follows closely the alternating monsoons (Wyrtki, 1961). During winter northeast monsoon, along the northern boundary, the warm and saline Kuroshio Current water with oligotrophic properties intrudes through Luzon Strait and flows westward along the continental margin of China to become the deep-water mass of the nSCS (Nitani, 1972; Shaw, 1991). The coastal water of the East China Sea flows southwestward through Taiwan Strait into the nSCS (Fang et al., 1998; Xue et al., 2004). On the contrary, during the summer southwest monsoon, the Guangdong Coastal Current flows eastward along the southern coast of mainland China, which eventually flows into the East China Sea through Taiwan Strait. The southwesterly winds also induce Ekman transport toward offshore and coastal upwelling. The deep water upwells and mixes with the upper water to form the SCS intermediate water, which flows out of the nSCS into the northwestern Pacific Ocean through Luzon Strait (Gong et al., 1992).

In the nSCS, the thermocline occurs all the year round, and the interannual change in its strength is pronounced (Yuan and Deng, 1997a, b; Shi et al., 2001). Previous studies have examined on variations in seawater temperature and salinity distributions (Yang and Liu, 1998; Yuan and Deng, 1998), dissolved oxygen distribution (Lin and Han, 1998), pollution status along the coast of the nSCS (Li and Chen, 1998) and the fisheries environment in the nSCS (Jia et al., 2005). Furthermore, it has been found that due to the combined effects of monsoons, topography, shape of the coastal line and the inertial effects, mesoscale eddies (Zeng et al., 1989; Xu et al., 2001; Li et al., 2003; Chen et al., 2005). Recent studies revealed that the effects of coupling between physical - chemical - biological oceanographic processes on phytoplankton biomass and production are important for understanding the influence on the long-term environmental changes and the ecosystem dynamics of the SCS (Liu et al., 2002, 2007; Ning et al., 2004).
However, the long term changes in environmental conditions and the responses of the ecosystem in this region have not been well documented yet. The objective of this study was to analyze the $29 \mathrm{y}$ time series of multidisciplinary observational data obtained during 1976-2004, aiming at understanding how the environment has changed and how the ecosystem and biological resources have responded to the environmental changes in the nSCS.

It must be pointed out that the data set we adopted in present analysis is large and from various sources (using data in this study were systemic maintained for the physicalchemical parameters, but for contemporaneous biological data were collected from various sources, and we have collected data from the same period of investigation as best as one can. Inevitably, there are some mismatches between the scales of physical and chemical parameters reflecting the processes of environmental change and the spatial and temporal dimensions of biological investigations, due to the less frequency for the latter). Although the quality of data might vary throughout the long period of observation, these data were valuable for the long term changes in environmental conditions and the responses of the ecosystem in this region. Using these data, we can still find some disciplines about the response of the ecosystem to the environmental change in the SCS. Regional response to global climate change is clearly a complicated issue, which is far from well understood. This study made an attempt to tackle this important issue. And in order to improve our understanding, additional long-term study is mandatory.

\section{Data and methods}

In this study, data were obtained from winter and summer monitoring along transect $\mathrm{N}$ (Fig. 1, an observation transect, including six stations, crossing the nSCS, from the northwestern to southeastern), maintained by the survey team of the State Oceanic Administration (SOA), China during 1976-2004. These data include physical [seawater temperature (T) and salinity (S)] and chemical parameters [dissolved oxygen (DO), phosphate $\left(\mathrm{PO}_{4}-\mathrm{P}\right)$, silicate $\left(\mathrm{SiO}_{3}-\mathrm{Si}\right)$, dissolved inorganic nitrogen (DIN, including $\mathrm{NO}_{3}-\mathrm{N}, \mathrm{NO}_{2}-\mathrm{N}$ and $\left.\mathrm{NH}_{4}-\mathrm{N}\right)$ ]. The parameters of $\mathrm{T}, \mathrm{S}$ and $\mathrm{DO}$ data collection started from 1976; and the nutrients data $\left(\mathrm{PO}_{4}-\mathrm{P}, \mathrm{SiO}_{3}-\mathrm{Si}\right.$, $\mathrm{NO}_{3}-\mathrm{N}, \mathrm{NO}_{2}-\mathrm{N}$ and $\mathrm{NH}_{4}-\mathrm{N}$ ) collection started from 1989. Seawater samples were collected using Nansen bottles from the surface, 5, 10, 15, 20, 25, 30, 35, 50, 75, 100, 150 and $200 \mathrm{~m}$ for $\mathrm{T}$ and $\mathrm{S}$, and at the surface, 10, 20, 30, 50, 75, 100, 150 and $200 \mathrm{~m}$ for biogenic element determination. Seawater temperature was measured by using a reversing thermometer attached to the Nansen bottle, and salinity was measured using induction salinometer, according to SOAC (1975) and NBTS (1991). Nutrients (nitrate, phosphate and silicate) were analyzed by standard spectrophotometric method, and dissolved oxygen (DO) was analyzed by the Winkler method 


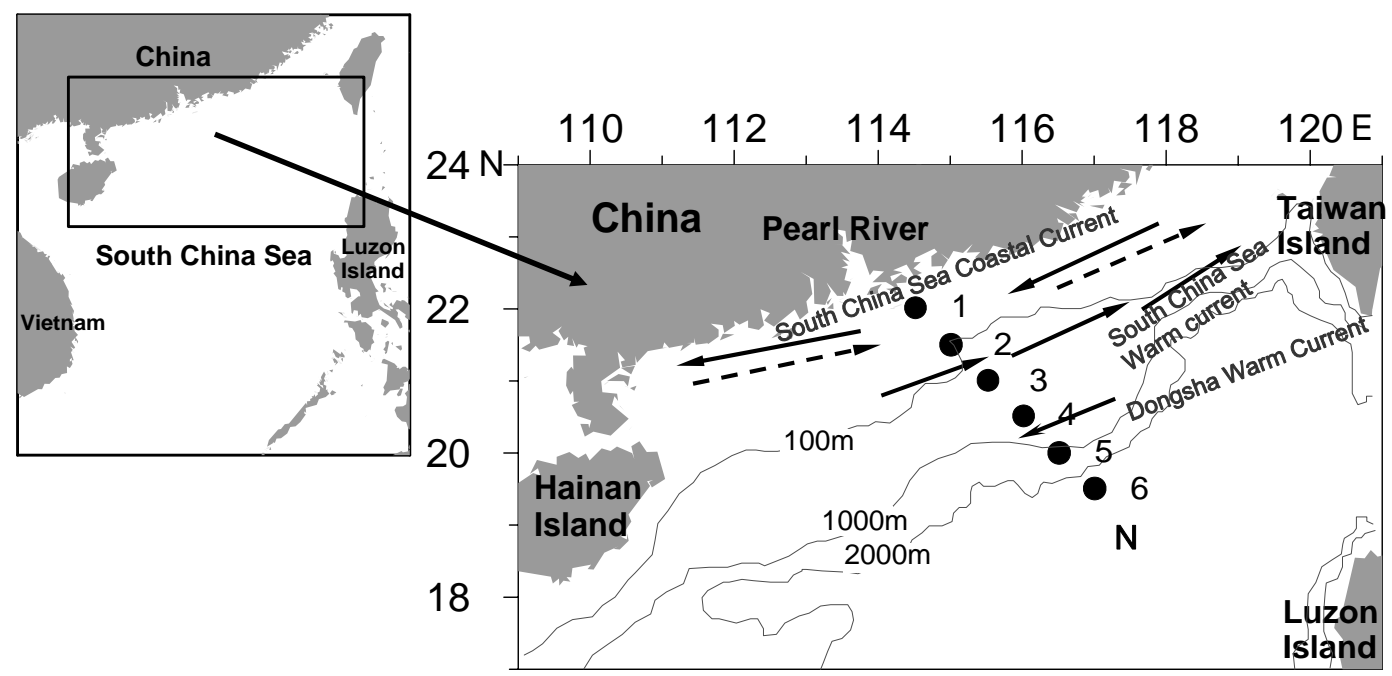

Fig. 1. Geographical locations of the transect and stations and the circulation in the northern South China Sea (nSCS) (modified from Su, 1998; Xue et al., 2004). Transect N from the Pearl River Estuary towards the southeastern nSCS is the main transect with 6 stations (full circle).

(Strickland and Parsons, 1972). Photosynthetic pigments (Chl- $a$ ) were measured by the acetone extraction and fluorescence method (Holm-Hansen et al., 1965).

Annual mean values were the average for winter and summer which were derived from observations during February and August, respectively. The regional average was the average value for the all stations illustrated in Fig. 1. First, we took the values at the sea surface (SS), the depth of $200 \mathrm{~m}$ and the average through the water column for 0-200 $\mathrm{m}$ (integrated) for each parameter for each station, since at the depth of $200 \mathrm{~m}$ concentrations of biogenic elements and other properties were relatively stable and much less influenced by the upper layers. Second, the regional means for each parameter on an annual scale were calculated. The average value for the water column was computed, according to the following equation:

$X_{a v}=\frac{1}{b} \int_{0}^{b} X(z) d z$

Where $X$ is an environmental parameter; $b$ is the water depth ( $200 \mathrm{~m}$, or $2 \mathrm{~m}$ above bottom if the water depth is shallower than $200 \mathrm{~m}$ ) and $z$ is the observation depth.

In order to show the interannual changes in environmental parameters in the nSCS, the time series of various parameters was determined. The parameters include physical parameters, such as SST, $T_{a v}, T_{200 \mathrm{~m}}, \mathrm{SSS}, S_{a v}, S_{200}$, and chemical parameters, such as SSDO, $\mathrm{DO}_{a v}, \mathrm{DO}_{200}, \mathrm{SSP}, P_{a v}, P_{200}$, $\mathrm{SSSi}, \mathrm{Si}_{a v}, \mathrm{Si}_{200}, \mathrm{SSDIN}, \mathrm{DIN}_{a v}, \mathrm{DIN}_{200}, \mathrm{SSNO}_{2}-\mathrm{N}, \mathrm{NO}_{2}-$ $\mathrm{N}_{a v}, \mathrm{NO}_{2}-\mathrm{N}_{200}, \mathrm{SSNO}_{3}-\mathrm{N}, \mathrm{NO}_{3}-\mathrm{N}_{a v}, \mathrm{NO}_{3}-\mathrm{N}_{200}, \mathrm{SSNH}_{4}-$ $\mathrm{N}, \mathrm{NH}_{4}-\mathrm{N}_{a v}, \mathrm{NH}_{4}-\mathrm{N}_{200}$, and the ratios of the chemical parameters SSN:SSP, $\mathrm{N}_{a v}: \mathrm{P}_{a v}, \mathrm{~N}_{200}: \mathrm{P}_{200}, \mathrm{SSSi}: S S N, \mathrm{Si}_{a v}: \mathrm{N}_{a v}$, $\mathrm{Si}_{200}: \mathrm{N}_{200}$, where av $=$ average for the whole water column and $200=200 \mathrm{~m}$ depth. Statistical test and linear regression analyses were conducted on time series (Chen and Ma, 1991) and climate trend coefficients $\left(R_{x t}\right)$ were estimated. $R_{x t}$ was used to assess whether there was a significant linear climatetrend in a time series (Shi et al., 1995). This coefficient was defined as the correlation coefficient between the time series of an environmental parameter, $\left\{X_{i}\right\}$, and the nature number $\{i\}, i=1,2,3 \ldots, n$. In this study, $n$ is the total span of the years covered by the data. The coefficient was computed from the following equation:

$R_{x t}=\frac{\sum_{i=1}^{n}\left(x_{i}-\bar{x}\right)(i-\bar{t})}{\sqrt{\sum_{i=1}^{n}\left(x_{i}-\bar{x}\right)^{2} \sum_{i=1}^{n}(i-\bar{t})^{2}}}$

Where $t=(n+1) / 2$. Its significance level is determined from the Student t-test. A positive/ negative value of $R_{x t}$ indicates that the time series, $\{\mathrm{Xi}\}$, has a linear positive/negative trend. In order to compare the environmental change rates between coastal/shelf waters with the slope/open sea, data for water depths $<200$ and $>200 \mathrm{~m}$, respectively, were analyzed.

Biological oceanography data, such as chlorophyll- $a$, phytoplankton abundance, primary production, zooplankton biomass, benthos biomass, cephalopod catch, etc. were obtained during the period by marine ecosystem surveys conducted by the South China Sea Fisheries Research Institute (SCSFRI), the South China Sea Institute of Oceanography, Chinese Academy of Sciences and the Second Institute of Oceanography, SOA. For the observational methods, Chl- $a$ was determined by acetone extraction fluorescence method (Holm-Hansen et al., 1965) and often calibrated by spectrophotometry. Primary productivity was measured using the ${ }^{14} \mathrm{C}$ tracer method established by Steemann-Nielsen 

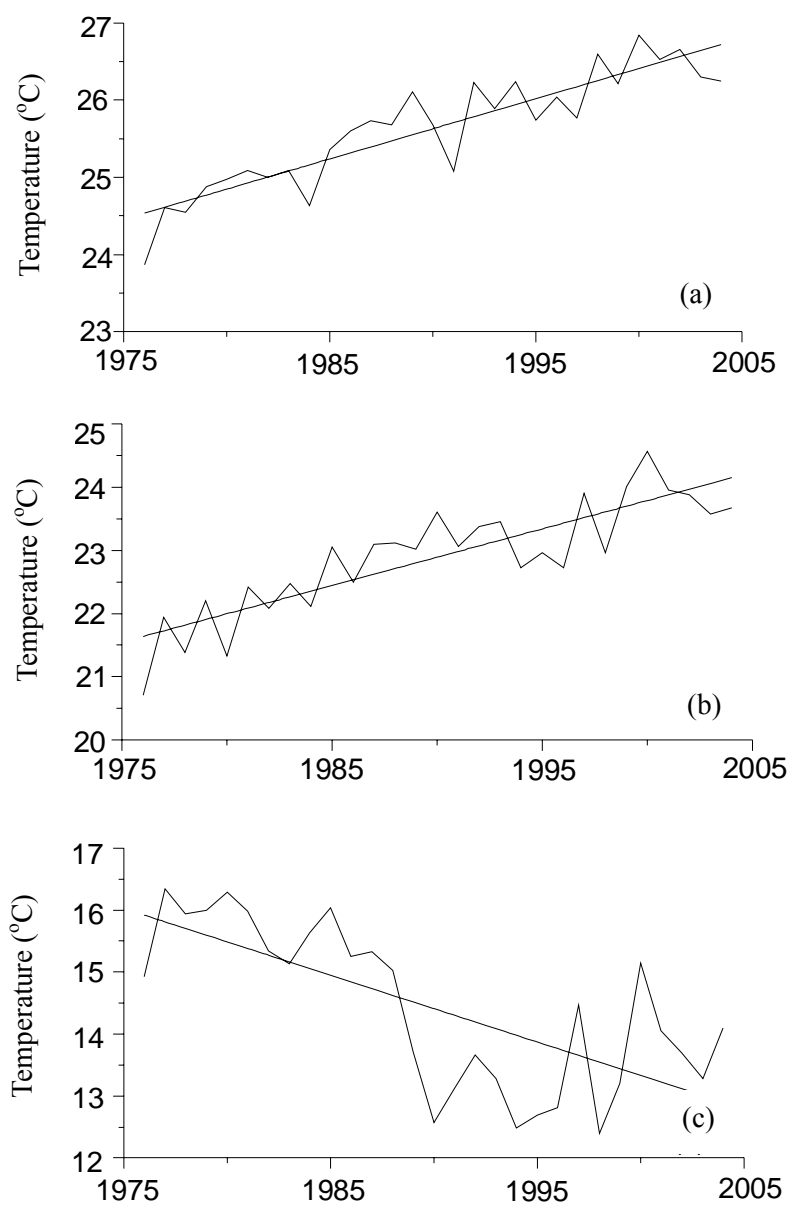

Fig. 2. Variation trends of seawater temperature in the nSCS during 1976-2004. (a), (b) and (c) show the annual mean of the sea surface temperature (SST), the water column average temperature in the upper $200 \mathrm{~m}\left(T_{a v}\right)$, and the temperature at the depth of $200 \mathrm{~m}$ $\left(T_{200}\right)$. The lines are the linear regressions.

(1952) and modified for scintillation counting by Wolfe and Schelske (1967). Phytoplankton samples were collected by vertical haul using a Judy net with a mesh size of $76 \mu \mathrm{m}$. The samples were preserved with Lugol's solution, and the species identification and cell counts were made using a microscope to get phytoplankton abundance (PA, Sournia, 1978). Zooplankton samples were collected by vertical haul using a plankton net with a mesh size of $505 \mu \mathrm{m}$, and the samples were preserved with neutral formaldehyde solution (5\%). The species identification and individual counts were made using a stereo microscope, and the wet weight biomass (ZB) was measured by an electronic balance after removing the body surface water in the lab, according to SOAC (1975) and NBTS (1991). Benthic macrofauna samples were collected by using a grab with a sampling area of $0.1 \mathrm{~m}^{2}$, and the animals were sorted after removing the mud by elutriation. The species identification and individual counts were made using a stereo microscope, and the wet weight biomass
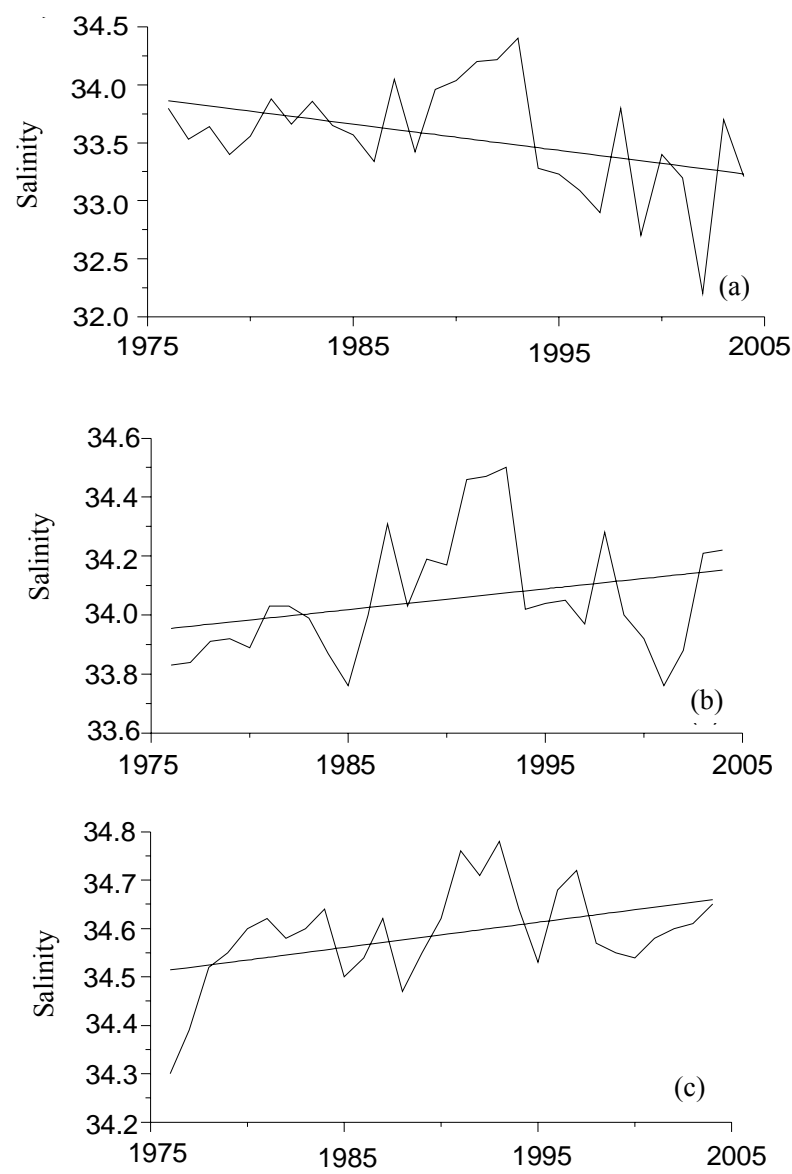

Fig. 3. Variation trends in seawater salinity in the nSCS during 1976-2004. (a), (b) and (c) show the annual means of sea surface salinity (SSS), water column average salinity in the upper $200 \mathrm{~m}$ $\left(S_{a v}\right)$ and salinity at $200 \mathrm{~m}\left(S_{200}\right)$, respectively. The lines are linear regressions.

(BB) was measured gravimetrically after removing the body surface water in the lab (SOAC, 1975; NBTS, 1991). The nekton samples were collected by using a cystoid net with a mesh size of $20 \mathrm{~mm}$, towed by a pair of boats at a speed of 3-4 kn for $1 \mathrm{~h}$ at each station (SOAC, 1975; NBTS, 1991).

\section{Results}

\subsection{Environmental changes during the 29 year time series}

\subsubsection{Seawater temperature and salinity}

The annual means of SST and $T_{a v}$ (the average temperature in the water column) exhibited highly significant increasing trends $(p \leq 0.01)$, their annual rates were 0.078 and $0.090^{\circ} \mathrm{C}$ $\mathrm{y}^{-1}$, respectively. However, the temperature at $200 \mathrm{~m}\left(T_{200}\right)$ showed a significant decreasing trend with an annual rate of $-0.108^{\circ} \mathrm{C}^{-1}$ during the 29 years of observation between 

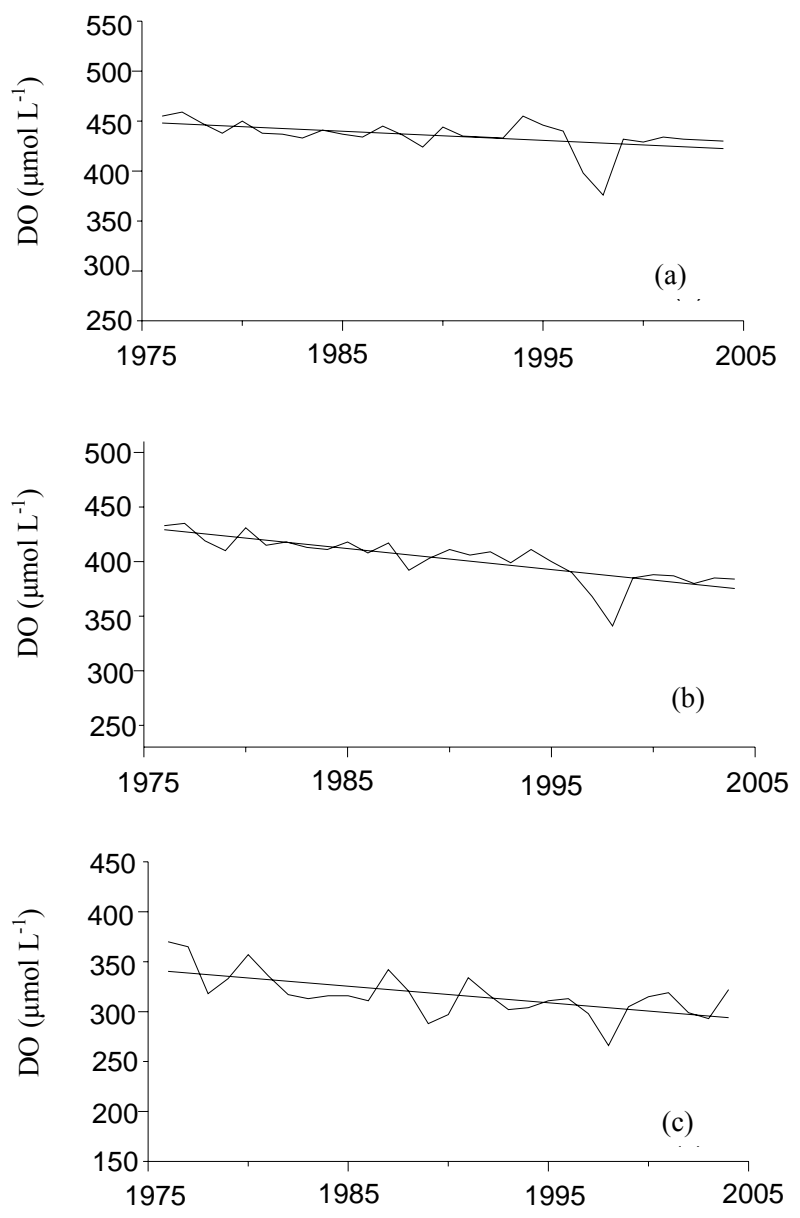

Fig. 4. Variation trends in dissolved oxygen (DO) concentration in the nSCS during 1976-2004. (a), (b) and (c) show the annual means of sea surface DO (SSDO), water column average in the upper $200 \mathrm{~m} \mathrm{DO}\left(\mathrm{DO}_{a v}\right)$ and $\mathrm{DO}$ at the $200 \mathrm{~m}\left(\mathrm{DO}_{200}\right)$, respectively. The lines are linear regressions.

1976 and 2004 (Fig. 2, Table 1). During this period, the SST and $T_{a v}$ increased by 2.26 and $2.61{ }^{\circ} \mathrm{C}$, respectively, while $T_{200}$ decreased by $3.10^{\circ} \mathrm{C}$ (Fig. 2, Table 1). The $R_{x t}$ of the time series of SST, $T_{a v}$ and $T_{200}$ were $0.89,0.85$ and -0.71 , respectively, and the variation trends for this time series were significant $(p \leq 0.01)$.

During the observation period the annual rate of SSS exhibited a decreasing trend $\left(-0.022 \mathrm{y}^{-1}\right)$, while the annual rates of $S_{a v}$ and $S_{200}$ exhibited increasing trend $\left(0.007 \mathrm{y}^{-1}\right.$ and $0.005 \mathrm{y}^{-1}$, respectively, Fig. 3, Table 1). The SSS decreased by 0.653 , while the $S_{a v}$ and $S_{200}$ increased by 0.206 and 0.151 . The $R_{x t}$ values of time series of SSS, $S_{a v}$ and $S_{200}$ were $-0.41(P \leq 0.05), 0.38(P \leq 0.05)$ and $0.44(p \leq 0.02)$, respectively (Table 1).
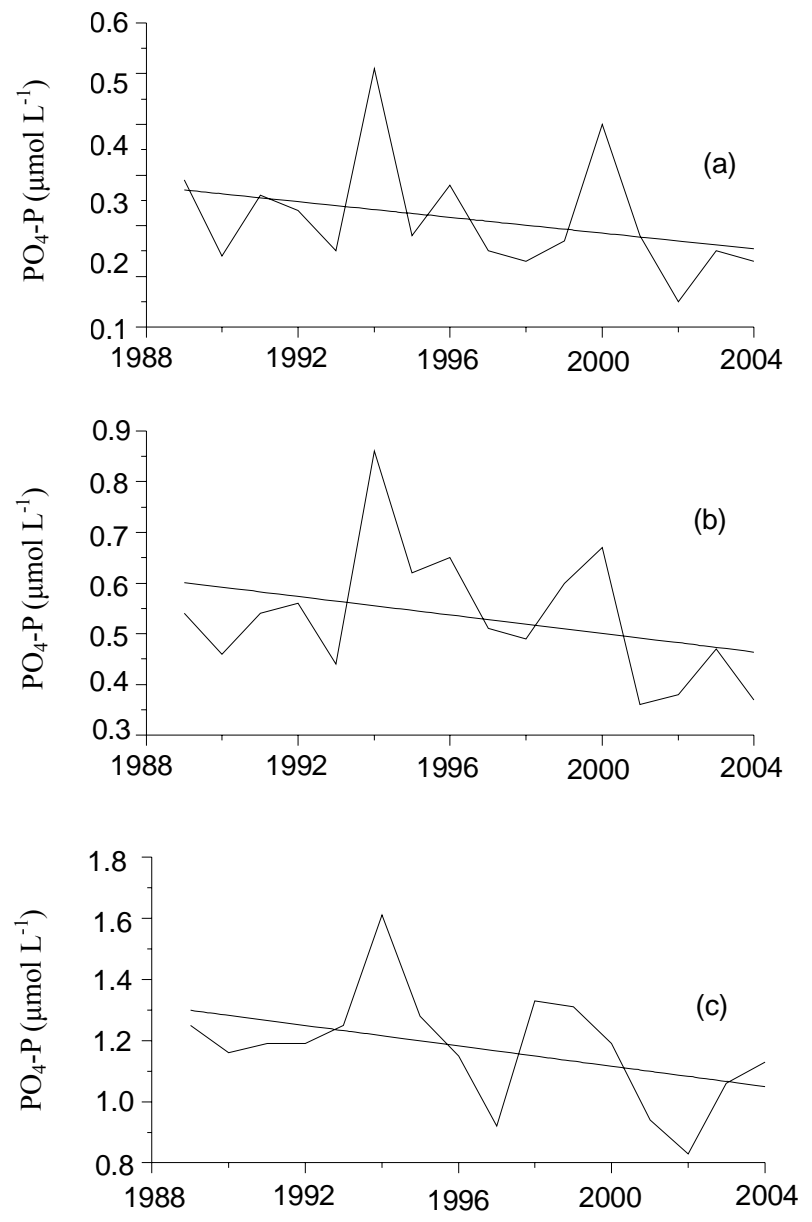

Fig. 5. Variation trends in $P$ concentrations in the nSCS during 1989-2004. (a), (b) and (c) show the annual means of sea surface $P$ (SSP), water column average $\mathrm{P}$ in the upper $200 \mathrm{~m}\left(\mathrm{P}_{a v}\right)$ and $\mathrm{P}$ in the $200 \mathrm{~m}$ layer $\left(\mathrm{P}_{200}\right)$, respectively. The lines are linear regressions.

\subsubsection{Concentration of dissolved oxygen (DO)}

A significant $(p \leq 0.01)$ decrease in DO concentrations was observed (Fig. 4; Table 1), and the annual rate was between -0.91 and $-1.93 \mu \mathrm{mol} \mathrm{L}^{-1} \mathrm{y}^{-1}$. The regional mean of DO of the sea surface, the water column average in the upper $200 \mathrm{~m}$ and at $200 \mathrm{~m}$ significantly decreased by $26.5,55.8$ and $47.9 \mu \mathrm{mol} \mathrm{L}^{-1}$. The $R_{x t}$ values of time series for DO ranged -0.48 to $-0.81(p \leq 0.01$, Table 1$)$.

\subsubsection{Concentrations of $\mathrm{P}, \mathrm{Si}$ and $\mathbf{N}$}

Both $\mathrm{P}$ and $\mathrm{Si}$ concentrations exhibited decreasing trends (Figs. 5 and 6, Table 1). Their annual rates were -0.008 to -0.017 (for P) and -0.071 to -0.387 (for Si) $\mu \mathrm{mol} \mathrm{L}^{-1} \mathrm{y}^{-1}$, respectively.

The concentrations of $\mathrm{NO}_{3}-\mathrm{N}, \mathrm{NO}_{2}-\mathrm{N}, \mathrm{NH}_{4}-\mathrm{N}$ and dissolved inorganic nitrogen $\left(\mathrm{DIN}=\mathrm{NO}_{3}+\mathrm{NO}_{2}+\mathrm{NH}_{4}\right)$ in the nSCS exhibited obvious increasing trends during 1989-2004 
Table 1. The annual rate, climate trend coefficients $\left(R_{x t}\right)$ and the amplitude of fluctuations of the environmental parameters in the nSCS during 1976-2004 (units: ${ }^{\circ} \mathrm{C}^{-1}$ for annual change in temperature, and $\mu \mathrm{mol} \mathrm{L}^{-1} \mathrm{y}^{-1}$ for DO and nutrients).

\begin{tabular}{|c|c|c|c|c|c|c|c|c|c|c|c|c|}
\hline & \multicolumn{3}{|c|}{ Annual rate } & \multicolumn{3}{|c|}{$R_{x t}^{\mathrm{a}}$} & \multicolumn{3}{|c|}{ Amplitude of fluctuation ${ }^{\mathrm{b}}$} & \multicolumn{3}{|c|}{ Mean $\pm \mathrm{SD}^{\mathrm{c}}$} \\
\hline & $\begin{array}{l}\text { Mean } \\
<200 \mathrm{~m}\end{array}$ & $\begin{array}{l}\text { Mean } \\
>200 \mathrm{~m}\end{array}$ & $\begin{array}{c}\text { Mean } \\
\text { whole area }\end{array}$ & $\begin{array}{l}\text { Mean } \\
<200 \mathrm{~m}\end{array}$ & $\begin{array}{l}\text { Mean } \\
>200 \mathrm{~m}\end{array}$ & $\begin{array}{c}\text { Mean } \\
\text { whole area }\end{array}$ & $\begin{array}{l}\text { Mean } \\
<200 \mathrm{~m}\end{array}$ & $\begin{array}{l}\text { Mean } \\
>200 \mathrm{~m}\end{array}$ & $\begin{array}{c}\text { Mean } \\
\text { whole area }\end{array}$ & $\begin{array}{l}\text { Mean } \\
<200 \mathrm{~m}\end{array}$ & $\begin{array}{c}\text { Mean } \\
>200 \mathrm{~m}\end{array}$ & $\begin{array}{c}\text { Mean } \\
\text { whole area }\end{array}$ \\
\hline SST & 0.078 & 0.063 & 0.078 & $0.84^{\mathrm{A}}$ & $0.80^{\mathrm{A}}$ & $0.89^{\mathrm{A}}$ & 2.67 & 3.28 & 2.97 & $24.75 \pm 1.82$ & $26.06 \pm 0.67$ & $25.63 \pm 0.74$ \\
\hline$T_{a v}$ & 0.089 & 0.095 & 0.090 & $0.80^{\mathrm{A}}$ & $0.85^{\mathrm{A}}$ & $0.85^{\mathrm{A}}$ & 4.07 & 4.41 & 3.86 & $23.49 \pm 0.97$ & $22.42 \pm 0.95$ & $22.29 \pm 0.89$ \\
\hline$T_{200}^{\mathrm{d}}$ & 0.045 & -0.107 & & $0.45^{\mathrm{B}}$ & $0.71^{\mathrm{A}}$ & & 2.90 & 3.94 & & $20.36 \pm 0.86$ & $15.41 \pm 1.30$ & \\
\hline SSS & -0.007 & -0.015 & -0.022 & -0.19 & -0.35 & $-0.41^{\mathrm{C}}$ & 3.61 & 2.30 & 2.20 & $33.10 \pm 0.78$ & $34.01 \pm 0.40$ & $33.55 \pm 0.48$ \\
\hline$S_{a v}$ & 0.008 & 0.005 & 0.007 & 0.32 & 0.34 & $0.38^{\mathrm{C}}$ & 0.97 & 0.71 & 0.74 & $33.89 \pm 0.30$ & $34.22 \pm 0.19$ & $34.05 \pm 0.21$ \\
\hline$S_{200}^{\mathrm{d}}$ & 0.005 & 0.005 & & 0.30 & $0.44^{\mathrm{B}}$ & & 0.42 & 0.48 & & $34.34 \pm 0.20$ & $34.59 \pm 0.10$ & \\
\hline SSDO & -0.964 & -0.927 & -0.913 & $-0.46^{\mathrm{B}}$ & $-0.52^{\mathrm{A}}$ & $-0.48^{\mathrm{A}}$ & 80 & 85 & 83 & $426.5 \pm 76.0$ & $425.4 \pm 15.0$ & $434.6 \pm 15.9$ \\
\hline $\mathrm{DO}_{a v}$ & -1.857 & -2.037 & -1.926 & $-0.67^{\mathrm{A}}$ & $-0.82^{\mathrm{A}}$ & $-0.81^{\mathrm{A}}$ & 102 & 92 & 94 & $422.6 \pm 33.0$ & $384.9 \pm 21.0$ & $402.3 \pm 20.3$ \\
\hline $\mathrm{DO}_{200}^{\mathrm{d}}$ & -2.230 & -1.653 & & $-0.70^{\mathrm{A}}$ & $-0.63^{\mathrm{A}}$ & & 99 & 104 & & $376.3 \pm 28.0$ & $317.2 \pm 22.4$ & \\
\hline $\mathrm{SSP}^{200}$ & -0.011 & -0.004 & -0.008 & -0.41 & -0.30 & -0.31 & 0.54 & 0.76 & 0.45 & $0.31 \pm 0.14$ & $0.32 \pm 0.11$ & $0.32 \pm 0.12$ \\
\hline$P_{a v}$ & -0.008 & -0.007 & -0.009 & -0.29 & -0.35 & -0.37 & 0.32 & 0.63 & 0.50 & $0.39 \pm 0.12$ & $0.69 \pm 0.17$ & $0.52 \pm 0.13$ \\
\hline$P_{200}^{\mathrm{d}}$ & -0.006 & -0.017 & & -0.22 & $-0.50^{\mathrm{D}}$ & & 0.48 & 0.78 & & $0.57 \pm 0.17$ & $1.19 \pm 0.21$ & \\
\hline SSSi & -0.642 & -0.284 & -0.071 & -0.19 & -0.30 & -0.22 & 12.19 & 12.90 & 11.50 & $9.93 \pm 3.46$ & $10.33 \pm 4.81$ & $10.20 \pm 3.71$ \\
\hline $\mathrm{Si}_{a v}$ & -0.284 & -0.240 & -0.161 & -0.24 & -0.19 & -0.16 & 17.84 & 21.46 & 17.86 & $11.51 \pm 6.05$ & $15.15 \pm 7.40$ & $12.64 \pm 7.17$ \\
\hline $\mathrm{Si}_{200}^{\mathrm{d}}$ & -0.038 & -0.387 & & -0.06 & -0.19 & & 17.57 & 32.50 & & $14.98 \pm 5.16$ & $26.80 \pm 9.53$ & \\
\hline SSDIN & 0.613 & 0.391 & 0.504 & $0.70^{\mathrm{A}}$ & $0.63^{\mathrm{A}}$ & $0.74^{\mathrm{A}}$ & 17.27 & 9.69 & 11.85 & $4.44 \pm 4.24$ & $3.73 \pm 3.00$ & $4.09 \pm 3.29$ \\
\hline $\operatorname{DIN}_{a v}$ & 0.416 & 0.343 & 0.381 & $0.75^{\mathrm{A}}$ & $0.61^{\mathrm{A}}$ & $0.73^{\mathrm{A}}$ & 9.68 & 10.53 & 10.53 & $4.71 \pm 2.63$ & $6.33 \pm 2.65$ & $6.71 \pm 2.60$ \\
\hline $\mathrm{DIN}_{200}^{\mathrm{d}}$ & 0.721 & 0.813 & & $0.73^{\mathrm{A}}$ & $0.64^{\mathrm{A}}$ & & 15.71 & 20.13 & & $7.61 \pm 4.68$ & $16.08 \pm 6.03$ & \\
\hline $\mathrm{SSNO}_{3}$ & 0.457 & 0.342 & 0.456 & $0.70^{\mathrm{A}}$ & $0.54^{\mathrm{D}}$ & $0.66^{\mathrm{A}}$ & 12.05 & 9.56 & 9.74 & $2.62 \pm 3.09$ & $2.45 \pm 2.99$ & $2.55 \pm 2.85$ \\
\hline $\mathrm{NO}_{3 a v}$ & 0.345 & 0.324 & 0.335 & $0.71^{\mathrm{A}}$ & $0.58^{\mathrm{B}}$ & $0.67^{\mathrm{A}}$ & 8.46 & 9.85 & 8.13 & $2.98 \pm 2.31$ & $5.09 \pm 2.68$ & $4.01 \pm 2.37$ \\
\hline $\mathrm{NO}_{3200}^{\mathrm{d}}$ & 0.582 & 0.711 & & $0.68^{\mathrm{A}}$ & $0.55^{\mathrm{C}}$ & & 13.57 & 20.55 & & $5.57 \pm 4.05$ & $14.53 \pm 6.17$ & \\
\hline SSDIN:SSP & 3.61 & 1.89 & 2.75 & $0.55^{\mathrm{C}}$ & $0.54^{\mathrm{D}}$ & $0.63^{\mathrm{A}}$ & 126.55 & 52.65 & 84.02 & $20.5 \pm 30.7$ & $14.9 \pm 16.8$ & $17.8 \pm 21.2$ \\
\hline $\mathrm{DIN}_{a v}: \mathrm{P}_{a v}$ & 1.66 & 0.75 & 1.21 & $0.70^{\mathrm{A}}$ & $0.57^{\mathrm{B}}$ & $0.69^{\mathrm{A}}$ & 40.26 & 23.24 & 28.65 & $14.0 \pm 11.3$ & $10.7 \pm 6.3$ & $12.3 \pm 8.4$ \\
\hline $\mathrm{DIN}_{200}: \mathrm{P}_{200}^{\mathrm{d}}$ & 1.51 & 1.04 & & $0.74^{\mathrm{A}}$ & $0.64^{\mathrm{A}}$ & & 31.26 & 27.3 & & $13.8 \pm 8.6$ & $14.0 \pm 7.8$ & \\
\hline SSSi:SSDIN & -0.52 & -0.46 & -0.44 & $-0.75^{\mathrm{A}}$ & -0.39 & $-0.67^{\mathrm{A}}$ & 12.32 & 22.68 & 9.69 & $4.1 \pm 3.3$ & $5.4 \pm 5.7$ & $4.3 \pm 3.2$ \\
\hline $\mathrm{Si}_{a v}: \mathrm{DIN}_{a v}$ & -0.46 & -0.15 & -0.22 & $-0.71^{\mathrm{A}}$ & -0.46 & $-0.70^{\mathrm{A}}$ & 13.05 & 5.62 & 5.41 & $3.4 \pm 3.1$ & $2.9 \pm 1.6$ & $2.8 \pm 1.5$ \\
\hline $\mathrm{Si}_{200}: \mathrm{DIN}_{200}^{\mathrm{d}}$ & -0.32 & -0.10 & & $-0.75^{\mathrm{A}}$ & $-0.65^{\mathrm{A}}$ & & 7.29 & 2.8 & & $2.87 \pm 2.02$ & $1.85 \pm 0.8$ & \\
\hline
\end{tabular}

a Significance: ${ }^{\mathrm{A}} p \leq 0.01,{ }^{\mathrm{B}} p \leq 0.02,{ }^{\mathrm{C}} p \leq 0.03$, and ${ }^{\mathrm{D}} p \leq 0.05$

$\mathrm{b}$ The amplitude is the difference between maximal annual mean value and minimal one during the observation period. It indicates quantitative characteristics of the fluctuation of a parameter during the observation period. Standard deviation is symbolized as $X_{\delta n-1}$.

${ }^{c}$ Mean \pm SD is the multi-year's mean value and standard deviation during the observation period.

d When the water depth $<200 \mathrm{~m}$, data for the bottom layer are used; when the water depth $>200 \mathrm{~m}$, data for $200 \mathrm{~m}$ were used.

(Fig. 7, Table 1). The annual rates of the increases in DIN and $\mathrm{NO}_{3}-\mathrm{N}$ were 0.38 to 0.81 and 0.34 to $0.71 \mu \mathrm{mol} \mathrm{L}^{-1} \mathrm{y}^{-1}$, respectively. The regional means of DIN values of the sea surface, water column average and $200 \mathrm{~m}$ layer increased by 8.06, 6.10 and $13.01 \mu \mathrm{mol} \mathrm{L}^{-1}$, respectively. DIN concentrations in the $200 \mathrm{~m}$ layer were significantly higher than those of the average for the water column and at the sea surface. Its annual rate was 1.61 times greater than that of the sea surface. And its multi-year average value during observation period was 3.9 times higher than that of the sea surface layer. The $R_{x t}$ value for the time series of $\mathrm{NO}_{3}-\mathrm{N}$ and DIN were between $0.55-0.74$. The variation trends of the $\mathrm{NO}_{3}-\mathrm{N}$ and DIN time series were highly significant $(p \leq 0.01)$ (Table 1), except for the time series of $\mathrm{NO}_{3}-\mathrm{N}_{200}$, which was significant $(p \leq 0.03)$. It was also found that the annual rate of DIN was higher in the shallow $(<200 \mathrm{~m})$ than in the deep water $(>200 \mathrm{~m})$ areas (Table 1$)$. The spatial-temporal distributions of the DIN $_{a v}$ (mean concentrations in the water column) indicated that since 1998 the high DIN Dvv $_{a v}$ concen- trations have exhibited a pronounced large area increasing, i.e. after 1998 in the most study area, DIN $_{a v}$ concentration $>5.71 \mu \mathrm{mol} \mathrm{L}^{-1}$ (Fig. 8, the shadow shows the area), and exceeded the low limit of suitable $\mathrm{N}$ concentration for diatom growth $\left(5.71 \mu \mathrm{mol} \mathrm{L}^{-1}\right.$, Chu, 1949). So it is favorable for phytoplankton growth in the most study area.

\subsubsection{Nutrient ratios}

During 1989-2004, the nutrient ratios (DIN:P and Si:DIN) changed significantly. For example, the DIN:P ratios increased by $1.04-2.75 \mathrm{y}^{-1}$, and it reached 28.1 (SSDIN:SSP) and $18.0\left(\mathrm{DIN}_{a v}: \mathrm{P}_{a v}\right)$ in 2004 (Fig. 9, Table 1); the Si: N ratios decreased at an annual rate of $-0.10 \sim-0.44 \mathrm{y}^{-1}$, and it dropped to 1.0 (SSSi:SSDIN) and $1.4\left(\mathrm{Si}_{a v}: \mathrm{DIN}_{a v}\right)$ in 2004 (Fig. 10, Table 1). The variation trends of all time series of $\mathrm{N}$ : $\mathrm{P}$ and $\mathrm{Si}$ : $\mathrm{N}$ were significant $(p \leq 0.01)$. The annual rates of increase in DIN:P and decrease in Si:DIN were higher in the shallow coastal waters $(<200 \mathrm{~m})$ than in deep continental shelf waters $(>200 \mathrm{~m})$ (Table 1$)$. 

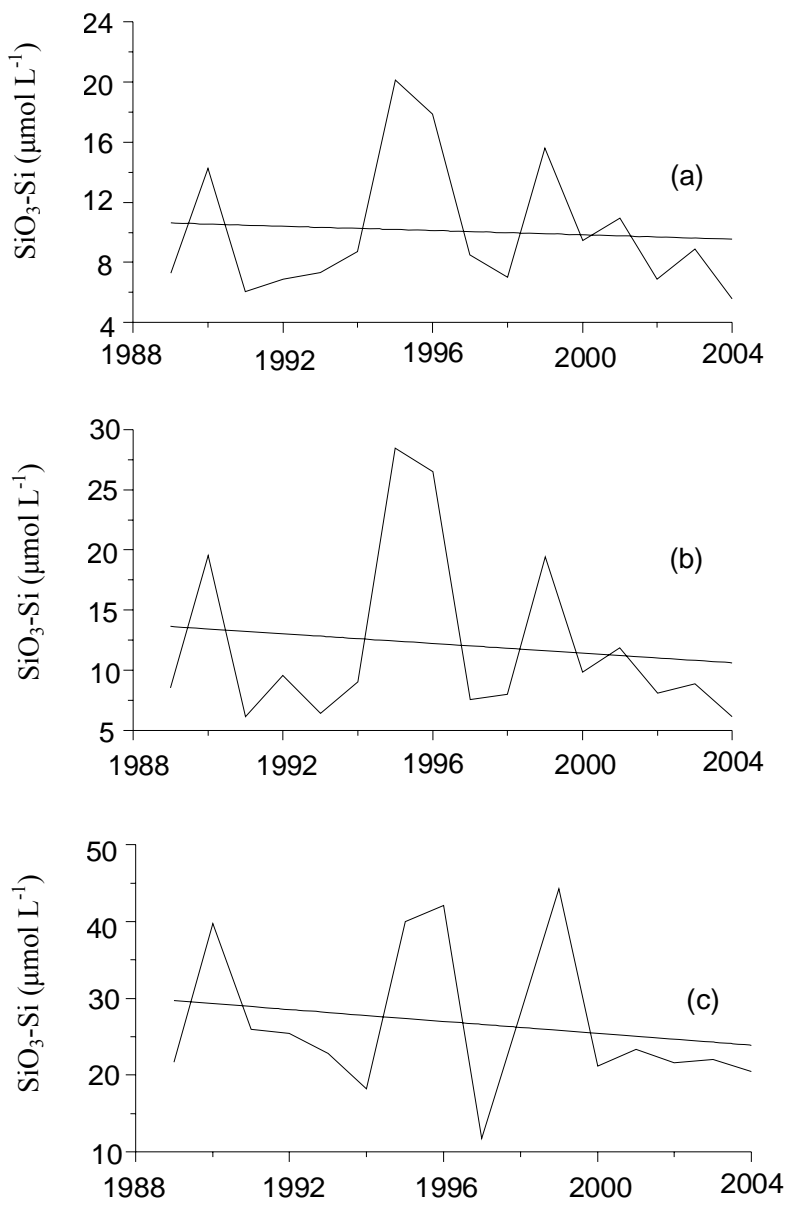

Fig. 6. Variation trends in $\mathrm{Si}$ concentrations in the nSCS during 1989-2004. (a), (b) and (c) show the annual means of sea surface $\mathrm{Si}$ (SSSi), water column average $\mathrm{Si}$ in the upper $200 \mathrm{~m}\left(\mathrm{Si}_{a v}\right)$ and $\mathrm{Si}$ in the $200 \mathrm{~m}$ layer $\left(\mathrm{Si}_{200}\right)$, respectively. The lines are linear regressions.

\section{Discussion}

\subsection{Increasing trends and the response of the ecosystem}

The positive increasing trends in SST and $T_{a v}$ in the nSCS during 1976-2004 are consistent with the increasing trends in the mean air temperature (AT) observed throughout the Northern Hemisphere (Houghton et al., 1996; Fu et al., 2006), South China (Chen et al., 1998; Chen et al., 1999; Zhai and Ren, 1997) and the annual means of AT and SST observed along the coast of the SCS (He et al., 2003; Martin and Arun, 2003). The increasing trends were also in phase with the changes in SST observed along the coast of the Yellow Sea and Bohai Sea (Lin et al., 2005, 2001). However, these annual rates of water temperature change were higher in the nSCS than in the Yellow Sea and the Bohai Sea (Lin et al., 2005, 2001).
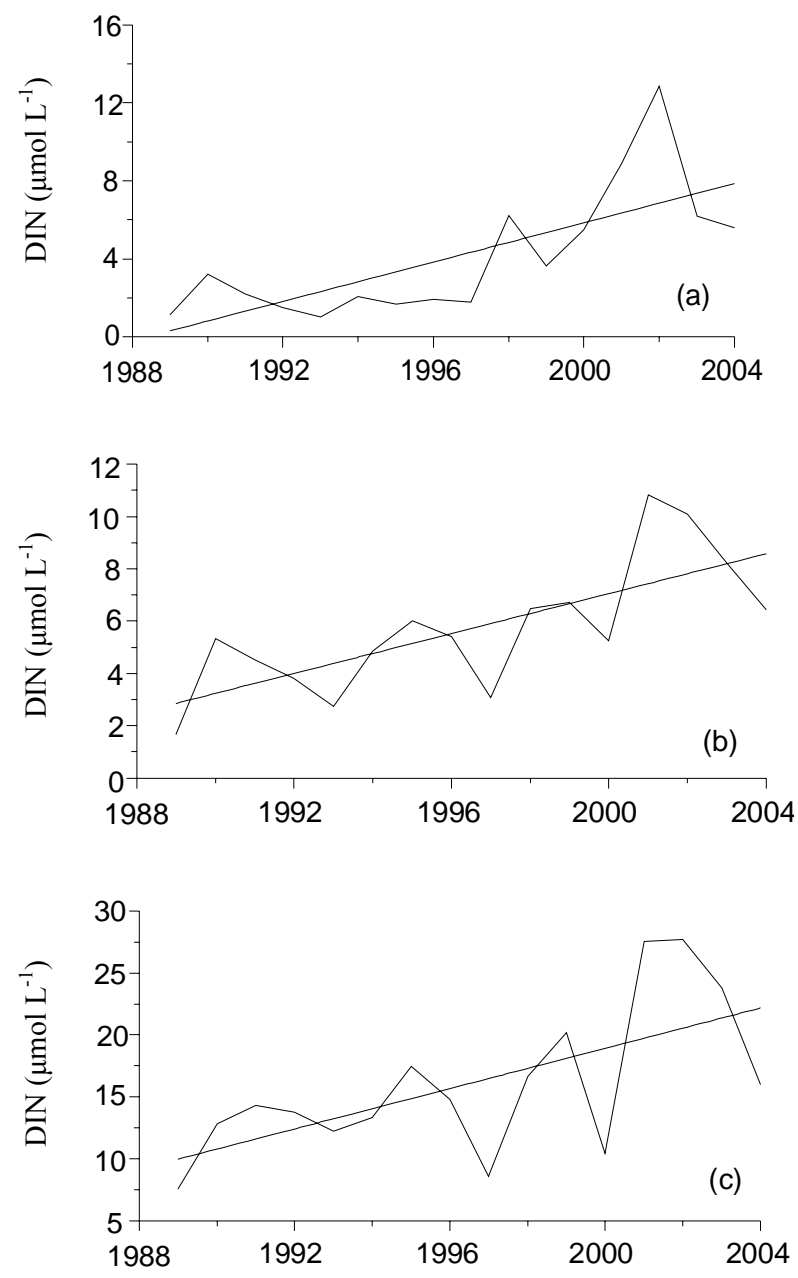

Fig. 7. Variation trends in dissolved inorganic nitrogen (DIN) concentrations in the nSCS during 1989-2004. (a), (b) and (c) show the annual means of sea surface DIN (SSDIN), water column average DIN in the upper $200 \mathrm{~m}\left(\mathrm{DIN}_{a v}\right)$ and DIN at the $200 \mathrm{~m}$ layer $\left(\mathrm{DIN}_{200}\right)$, respectively. The lines are linear regressions.

The increase in DIN in the nSCS during 1989-2004 was consistent with the increase in DIN along the coast of the nSCS, such as Qinzhou Bay (Wei et al., 2002, 2003) and Daya Bay (Qiu et al., 2005). It also shows the same trend with the rise of DIN observed throughout the global marginal seas (Seitzinger et al., 2002). Along with the rapid economic development in China, DIN concentration in the Pearl River estuary and shelf of the China Sea has been dramatically increased, due to the increasing urbanization near the coastal areas, which resulted in more municipal sewage, agricultural fertilizer, mariculture waste etc. inputs (SOAC, 2001). Through analysis based on DIN and PN models, combining with spatially explicit global databases, Seitzinger et al. (2002) showed that DIN input rates increased from approximately $21 \mathrm{Tg} \mathrm{N} \mathrm{y}^{-1}$ in 1990 to $47 \mathrm{Tg} \mathrm{N} \mathrm{y}^{-1}$ by 2050 . The largest increases are predicted for Southern and Eastern 


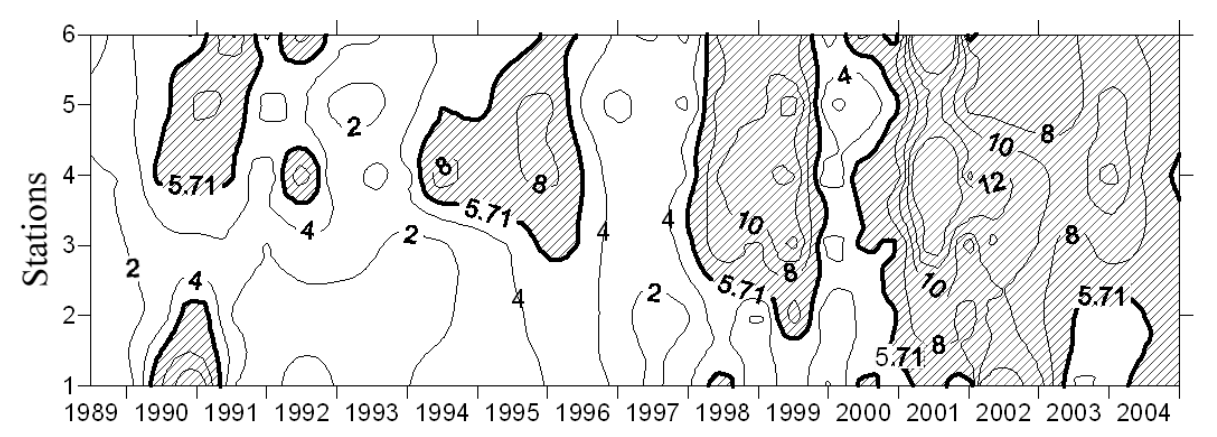

Fig. 8. The spatial-temporal distributions of the $\operatorname{DIN}_{a v}$ (mean concentrations in the water column). The shadow shows the area and period of time which exceeded the low limit of suitable $\mathrm{N}$ concentration for diatom growth $\left(5.71 \mu \mathrm{mol} \mathrm{L}^{-1}\right.$, Chu, 1949).

Table 2. Changes in annually average concentration $\left(\mu \mathrm{mol} \mathrm{dm}{ }^{-3}\right)$ of $\mathrm{NO}_{3}-\mathrm{N}$ and dissolved inorganic nitrogen (DIN), from discharges of the Pearl River and other rivers.

\begin{tabular}{llll}
\hline Observation year & Location of the observation & Parameter, value & Data source \\
\hline $1980-1985$ & southern Hong Kong waters (outside Pearl River estuary) & $\mathrm{NO}_{3}-\mathrm{N}, 1-3$ & Han et al. (1990) \\
1986 & Pearl River estuary & DIN, 19.3 & He et al. (2004) \\
1987 & Pearl River estuary & $\mathrm{NO}_{3}-\mathrm{N}$, 28.0 DIN, 31.7 & Wang and Peng (1996) \\
1990 & Pearl River estuary & DIN, 34.6 & He et al. (2004) \\
1995 & Pearl River estuary & DIN, 36.4 & He et al. (2004) \\
1996 & Pearl River estuary & $\mathrm{NO}_{3}-\mathrm{N}, 39.8$ & Cai (2002b) \\
1999 (summer) & Pearl River estuary & $\mathrm{NO}_{3}-\mathrm{N}, 48.9$ DIN, 51.9 & Lin et al. (2004) \\
1999 (summer) & Pearl River estuary & DIN, 53.2 & Guan et al. (2003) \\
2002 & Pearl River estuary & DIN, 76.4 & He et al. (2004) \\
\hline
\end{tabular}

Asia, associated with predicted large increases in population, will increase fertilizer use, and increased industrialization. DIN from the Pearl River discharge increased by 3 times in 2002 as compared to 1986 (He et al., 2004, Table 2), and $\mathrm{NO}_{3}-\mathrm{N}$ input from the Pearl in River Estuary was 1.7 times in 1999 of that in 1987 (Guan et al., 2003; Wang and Peng, 1996, Table 2). SSDIN should be influenced by the increase in DIN from the river discharges. In addition, significant inputs of DIN into the nSCS have also occurred through atmospheric dry and wet deposition (Zhang et al., 1999) and the upwelling of the deep waters (Zhao et al., 2005). The mitigation of N limitation in the upper layer since 1998 was clearly related to these DIN inputs (Fig. 8). The increase in the annual rate of DIN was higher at the $200 \mathrm{~m}$ layer $\left(\mathrm{DIN}_{200}\right)$ than the water column average ( $\operatorname{DIN}_{a v}$ ) and at the sea surface layer (SSDIN). This may be due to possible strengthening of the deep water upwelling. However, during 1989-1997, the DIN $_{a v}$ was low, the multi-annual mean was $4.2 \mu \mathrm{mol} \mathrm{L}^{-1}$ and the lowest value of $\operatorname{DIN}_{a v}$ was only $1.7 \mu \mathrm{mol} \mathrm{L}^{-1}$ in 1989. Since 1998, the multi-annual mean of the water column average DIN concentration has reached $7.7 \mu \mathrm{mol} \mathrm{L}^{-1}$ and the maximal value of the annual mean even reached up to $10.8 \mu \mathrm{mol} \mathrm{L}^{-1}$ in 2001 (Fig. 7b). And therefore, the previous status of $\mathrm{N}$ limitation in the $\mathrm{nSCS}$ was significantly al- leviated. Moreover, the increases in the annual rates of DIN and $\mathrm{NO}_{3}-\mathrm{N}$ were much higher in the nSCS than in the Yellow Sea (Lin et al., 2005).

The increase in the N:P ratio was due to an increase in DIN and a decrease in P concentration. Before 1997, the N:P ratios (SSN:SSP, DIN ${ }_{a v}: \mathrm{P}_{a v}$ and $\mathrm{DIN}_{200}: \mathrm{P}_{200}$ ) were lower than 10 . Since 1998 , these ratios have rapidly increased to 28, 18 and 16 in 2004, respectively (Fig. 9). In 2004, the average values of $\mathrm{DIN}_{a v}: \mathrm{P}_{a v}$ and $\mathrm{DIN}_{200}: \mathrm{P}_{200}$ were close to the Redfield ratio (16:1), and therefore favorable to phytoplankton growth (Richardson, 1997; Hu et al., 1989; Jiang and Yao, 1999). The high value of SSN:SSP (28) in 2004 was probably due to dry and wet deposition. The peak value of SSN:SSP appeared in 2002 (up to 86, Fig. 8a), due mainly to high rainfall as high Pearl River discharge, and this high ratio corresponded to the lowest surface salinity (Fig. 3a). Moreover, the fact that the annual rates of DIN and DIN:P were higher in the shallow water area $(<200 \mathrm{~m})$ than in the deep water area $(>200 \mathrm{~m}$ ) (Table 1) suggested the influence of the anthropogenic activities on the ecosystems of the shallow or coastal waters. These results agree well with $\mathrm{Xu}$ et al. (2008) who also showed that $\mathrm{N}$ input from the Pearl River has caused the nSCS to become P-limited. Phosphate decline may be ascribed to the implementation of phosphate 

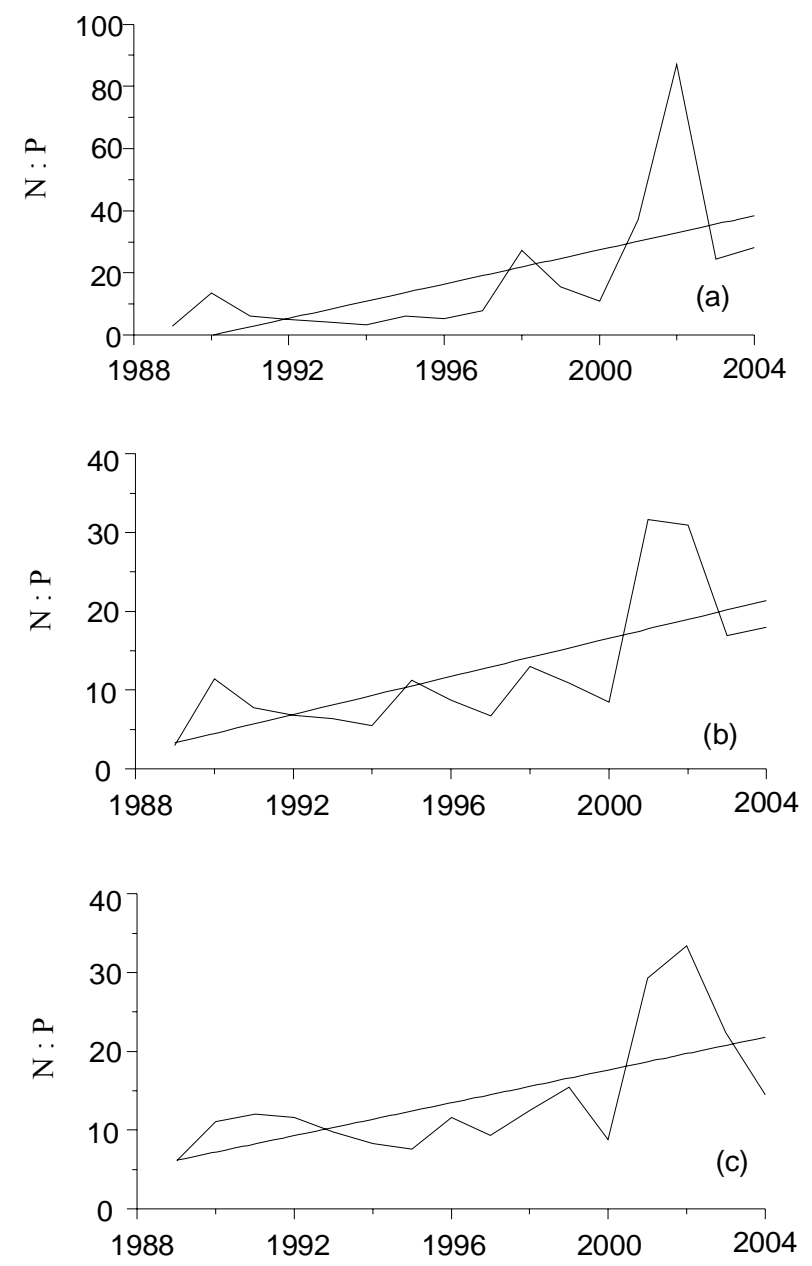

Fig. 9. Variation trends in N: P ratios in the nSCS during 19892004. (a), (b) and (c) show the annual means of sea surface DIN:P (SSDIN:SSP), water column average DIN:P in the upper $200 \mathrm{~m}$ $\left(\mathrm{DIN}_{a v}: \mathrm{P}_{a v}\right)$ and DIN:P at the $200 \mathrm{~m}$ layer $\left(\mathrm{DIN}_{200}: \mathrm{P}_{200}\right)$, respectively. The lines are linear regressions.

detergent ban in the late 1990s, and phytoplankton great consumption.

\subsection{Decreasing trends and the response of the ecosystem}

The decreasing trends in SSS may be related to the increase in the freshwater discharge into the nSCS since 1990 and less vertical mixing, because of the presence of a permanent thermocline (Yuan and Deng, 1997a, b; Shi, 2001). It has previously been observed that the occurrence of low SSS often corresponded to abnormally high discharge of the Pearl River (Xie and Zhang, 2003; Xu et al., 2008). During the period of 1990 to 2000, the Pearl River runoff increased by $22.5 \%$ in comparison with the mean discharge for 1960 1999 (Lei et al., 2003). In the 1990s (i.e. 1994, 1995, 1996, 1997, 1999) and 2002, SSS in the nSCS was especially low (Fig. 3a), which was induced by the Pearl River floods (Lei
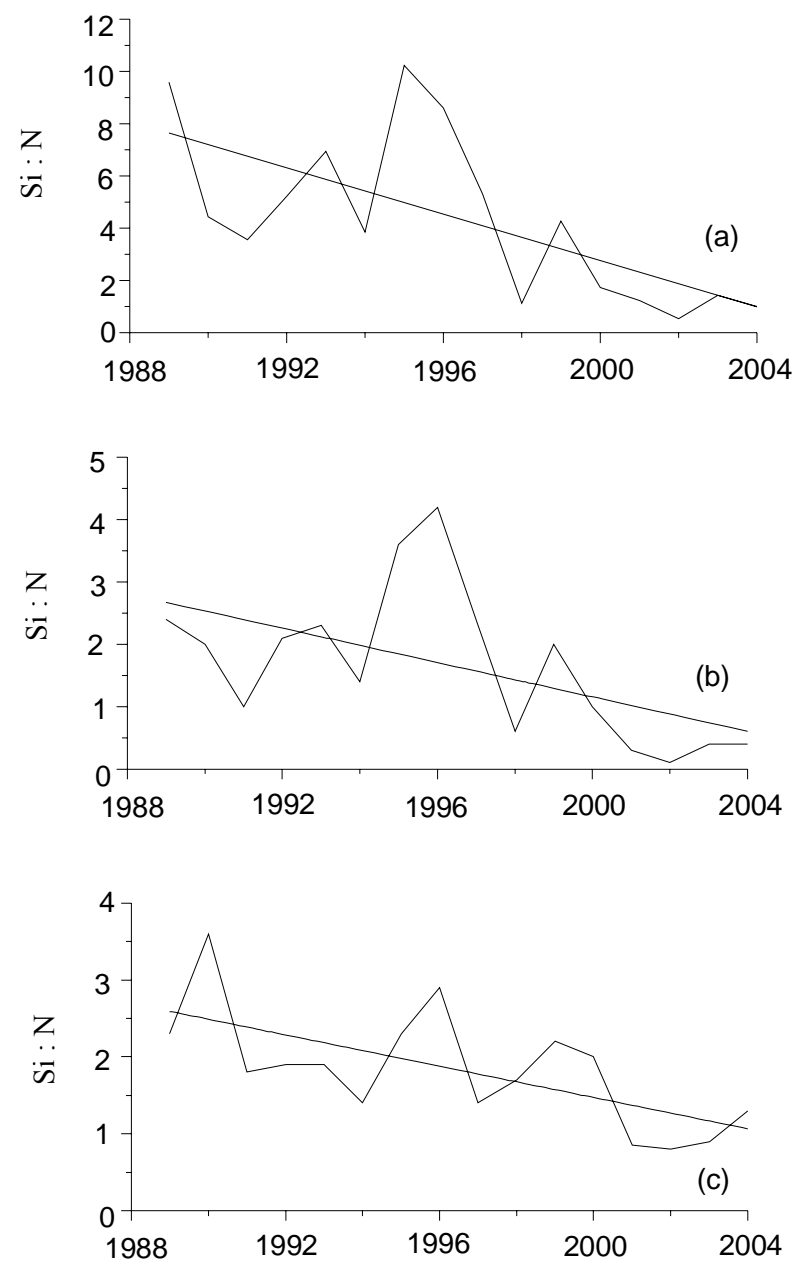

Fig. 10. Variation trends in Si: N ratios in the nSCS during 19892004. (a), (b) and (c) show the annual means of sea surface Si:N (SSSi: SSDIN), water column average Si:N in the upper $200 \mathrm{~m}$ $\left(\mathrm{Si}_{a v}: \mathrm{DIN}_{a v}\right)$ and $\mathrm{Si}: \mathrm{N}$ at the $200 \mathrm{~m}$ layer $\left(\mathrm{Si}_{200}: \mathrm{DIN}_{200}\right)$, respectively. The lines are linear regressions.

et al., 2003). Particularly in 2002, the strongest typhoon rain storm resulted in the historically greatest flood of the Pearl River, and therefore, which induced in the lowest SSS (32.2) in the nSCS during that study period (Lei et al., 2003; Xie and Zhang, 2003). In 1999, the SSS was below normal due to the influence of frequent typhoon rain storms (total of 28 typhoons, including 7 landed ones). Furthermore, in the summer of 1999, the Dongsha upwelling (Station 3-6) was weak and the depth of the $20^{\circ} \mathrm{C}$ isopleth was deeper than $105 \mathrm{~m}$. However in 1998, although large floods of the Pearl River occurred, the SSS did not decrease, due to the strong upwelling as indicated by shallow $(84 \mathrm{~m})$ depth of the $20^{\circ} \mathrm{C}$ isopleths. Chai et al. (2001) pointed out that the strength of upwelling can be indicated by the depth of $20^{\circ} \mathrm{C}$ temperature isopleth in the SCS. In this study, the range depth of $20^{\circ} \mathrm{C}$ isopleths is $84-150 \mathrm{~m}$. However, the high SSS in 1993 was probably due to the reduced Pearl River discharge (Lei et al., 2003). 
Table 3. Comparison of key nutrient concentration $\left(\mu \mathrm{mol} \mathrm{L}^{-1}\right)$ and the ratio between the two phases (before 1997, the first phase and after 1997, the second phase).

\begin{tabular}{lcc}
\hline Nutrient and ratio & $\begin{array}{c}\text { mean in the } \\
\text { first phase }\end{array}$ & $\begin{array}{c}\text { mean in the } \\
\text { second phase }\end{array}$ \\
\hline $\mathrm{SSDIN}_{\mathrm{DIN}}$ & 1.83 & 5.75 \\
$\mathrm{DIN}_{200}$ & 4.22 & 7.78 \\
$\mathrm{SSP}$ & 12.77 & 20.33 \\
$\mathrm{P}_{a v}$ & 0.33 & 0.25 \\
$\mathrm{P}_{200}$ & 0.56 & 0.48 \\
$\mathrm{SSSi}$ & 0.49 & 0.48 \\
$\mathrm{Si}_{a v}$ & 12.38 & 9.19 \\
$\mathrm{Si}_{200}$ & 14.82 & 12.26 \\
$\mathrm{SSDIN}_{2 S S P}$ & 27.54 & 25.85 \\
$\mathrm{DIN}_{a v}: \mathrm{P}_{a v}$ & 5.5 & 23.0 \\
$\mathrm{DIN}_{200}: \mathrm{P}_{200}$ & 7.5 & 16.2 \\
$\mathrm{SSSi}_{\mathrm{SSDIN}}$ & 26.1 & 42.4 \\
$\mathrm{Si}_{a v}: \mathrm{DIN}$ & 6.3 & 1.6 \\
$\mathrm{Si}_{200}: \mathrm{DIN}$ & 2.5 & 1.6 \\
$\mathrm{SSSi}_{200}$ & 2.2 & 1.3 \\
$\mathrm{Si}_{a v}: \mathrm{P}_{a v}$ & 37.5 & 36.8 \\
$\mathrm{Si}_{200}: \mathrm{P}_{200}$ & 26.5 & 25.5 \\
\hline & 56.2 & 53.8 \\
\hline
\end{tabular}

The decreasing trend in DO concentration (Fig. 4) can probably be attributed to three reasons. First, a small decrease in DO solubility in the seawater can be induced by the increase in the seawater temperature (Fig. 2). Second, an increase in DO consumption was an important reason. The DO consumption resulted from the decomposition of organic matter originating mainly from the Pearl River discharge and the decay of phytoplankton blooms with increasing frequencies in the coastal water was increasing (Peng, 1994; Tang et al., 2006). Before 1998, HABs (harmful algae blooms) occurred once or twice a year, but during 1998 to 2003, blooms increased to 10 to 20 a year in the nSCS (Tang et al., 2006), which was in phase with the dramatic decreasing trend in DO (Fig. 4). Third, the mixing between the surface water and the deep layers was reduced by the stronger thermocline, due to the rapid rise in SST since 1995 (Fig. 2a), which resulted in less transfer of oxygen from the atmosphere to the deeper waters. In addition in 1998, the lowest value of DO was probably attributed to the strongest upwelling, which occurred that year. According to the compute of this study, in 1998 the depth of the $20^{\circ} \mathrm{C}$ isopleths was $84 \mathrm{~m}$, it show the strongest upwelling (see above paragraph and references in it).

The decrease in $\mathrm{P}$ concentration is probably due to uptake by phytoplankton and less P supply from deep water, due to the presence of the permanent thermocline (Yuan and Deng, 1997a, b; Shi et al., 2001). Furthermore, since 1998, the reduction in $\mathrm{N}$ limitation has increased the phytoplank- ton biomass and production (Table 3) and decreased the $\mathrm{P}$ concentration. Hong et al. (1983) reported that diatoms can take up 30 times more $\mathrm{P}$ than they need and store it for use when $\mathrm{P}$ is deficient. In the most years except for 1994 and 2000 , the concentrations of $\mathrm{P}$ in the upper layer $(<75 \mathrm{~m})$ were even lower than the $\mathrm{P}$ concentration required for diatom growth $(<0.1 \mu \mathrm{mol} \mathrm{L}-1$, Zou et al., 1983). The decreasing trends in Si concentration have probably been influenced by the decrease in Si concentration in the Pearl River runoff since the 1970s (Lei et al., 2003), but still adequate for diatom growth. At $200 \mathrm{~m}$, the interannual fluctuations of both P and Si concentrations were high (Figs. 5 and 6) and probably attributed to the interannual changes in upwelling of deep water. In 1996 and 1999 the depth of the $20^{\circ}$ isopleth was shallow (average value from multi-stations was $93 \mathrm{~m}$ ), high concentrations of $\mathrm{P}$ and $\mathrm{Si}$ occurred $\left(\mathrm{P}_{a v}=0.61\right.$ and $0.62 \mu \mathrm{mol} \mathrm{L}^{-1}, \mathrm{P}_{200}=1.154$ and $1.31 \mu \mathrm{mol} \mathrm{L}^{-1}, \mathrm{Si}_{a v}=25.18$ and $19.55 \mu \mathrm{mol} \mathrm{L}^{-1}$, and $\mathrm{Si}_{200}=42.12$ and $44.28 \mu \mathrm{mol} \mathrm{L}^{-1}$, respectively, in the two years). In contrast, during 2004 when the depth of the $20^{\circ}$ isopleth was deep ((the average value from multi-stations was $105 \mathrm{~m}$ ), concentrations of $\mathrm{P}\left(\mathrm{P}_{a v}=0.37 \mu \mathrm{mol} \mathrm{L}^{-1}\right.$, and $\left.\mathrm{P}_{200}=1.13 \mu \mathrm{mol} \mathrm{L}^{-1}\right)$ and $\mathrm{Si}$

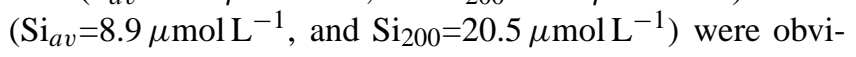
ously low.

\subsection{Nutrient limitation}

Since 1998, DIN concentrations have exhibited a pronounced increasing trend, and therefore the key nutrient concentration and ratio can be divided into two phases, i.e. before and after 1997 (Table 3). In the first phase, the average DIN concentration was very low, SSDIN and $\operatorname{DIN}_{a v}$ were 1.83 and $4.22 \mu \mathrm{mol} \mathrm{L}^{-1}$, respectively, which were lower than the low limit of suitable $\mathrm{N}$ concentration for diatom growth (5.71 $\mu \mathrm{mol} \mathrm{L}^{-1}$, Chu, 1949). The average $\mathrm{P}$ concentration was also low. SSP and $\mathrm{P}_{a v}$ were 0.33 and $0.56 \mu \mathrm{mol} \mathrm{L}^{-1}$, respectively, which is closed to the low limit of suitable $\mathrm{P}$ concentration for diatom growth $\left(0.48 \mu \mathrm{mol} \mathrm{L}^{-1}\right.$, Zhao et al., 2000). However, Si concentrations (SSSi and $\mathrm{Si}_{a v}$ were 12.38 and $14.82 \mu \mathrm{mol} \mathrm{L}^{-1}$, respectively) outclassed the low limit of suitable for diatom growth $\left(4.40 \mu \mathrm{mol} \mathrm{L}^{-1}\right.$, Harvey, 1957). Therefore, Si pool was sufficient. N:P ratios were less than half the Redfield ratio of 16 (SSN:SSP and $\mathrm{N}_{a v}: \mathrm{P}_{a v}$ were 5.5 and 7.5 , respectively).

In contrast, for the second phase after 1997, the average DIN concentration has been clearly increasing (SSDIN and $\mathrm{DIN}_{a v}$ were 5.75 and $7.78 \mu \mathrm{mol} \mathrm{L}^{-1}$ respectively, Table 3), and exceeded the low limit of suitable $\mathrm{N}$ concentration for diatom growth $\left(5.71 \mu \mathrm{mol} \mathrm{L}^{-1}\right.$, Chu, 1949). However, the average $\mathrm{P}$ concentration has decreased (SSP and $\mathrm{P}_{a v}$, were 0.25 and $0.48 \mu \mathrm{mol} \mathrm{L}^{-1}$, respectively, Table 3). Consequently, there was a rapid increase in DIN:P ratios (SSDIN:SSP and DIN ${ }_{a v}: \mathrm{P}_{a v}$ were 23.0 and 16.2, respectively, Table 3), which were close to the Redfield ratio (16, Richardson, 1997; Hutchins et al., 1998). Therefore, it is favorable to 
phytoplankton growth in the second phase. Si concentration also decreased (SSSi and $\mathrm{Si}_{a v}$ were 9.19 and 12.26) in this phase, resulting in rapid decrease in the ratio of SSSi:SSDIN $\left(\mathrm{Si}_{a v}: \mathrm{DIN}_{a v}\right)$, from 6.3 (2.5) to 1.6 (1.6) (Table 3). The Si concentration decrease may be due to the dam of the river courses which significantly reduced the silica delivery to the SCS.

Based on the studies on the kinetics of nutrient uptake, the thresholds of $\mathrm{SiO}_{3}-\mathrm{Si}$, DIN and $\mathrm{PO}_{4}-\mathrm{P}$ for phytoplankton growth have been estimated to be 2.0, 1.0 and $0.1 \mu \mathrm{mol} \mathrm{L}^{-1}$, respectively (Justic et al., 1995). In the study area, the values of all the nutrient parameters were over these threshold concentrations, except for those in the first phase, when the mean of SSDIN was close to the threshold of N (Table 3). According to chemical stoichiometry, in the first phase both SSN:SSP and $\operatorname{DIN}_{a v}: \mathrm{P}_{a v}$ was lower than 10, and SSSi:SSDIN, $\mathrm{Si}_{a v}: \mathrm{DIN}_{a v}$ and $\mathrm{Si}_{200}: \mathrm{DIN}_{200}$ were all over 1, indicating potential $\mathrm{N}$ limitation. In the second phase SSDIN:SSP and $\mathrm{DIN}_{200}: \mathrm{P}_{200}$ were higher than 22, and $\mathrm{DIN}_{a v}: \mathrm{P}_{a v}$ was equal to the Redfield ratio. All Si:DIN ratios ranged from 1.3 to 1.6 , and $\mathrm{Si}: \mathrm{P}$ ranged 25.5 to 53.8 (Table 3), which indicated that the potential of $\mathrm{P}$ limitation increased and $\mathrm{N}$ limitation decreased. Furthermore, Si was always sufficient during the observation period, even in the second phase when its concentration decreased (Table 3).

\subsection{Response of ecological environment to ENSO events}

When El Nino occurs, the warm pool of the western Pacific Ocean moves eastward, whereas it moves westward during La Nina (White et al., 1985; Takeuchi, 1987; Zhang and Huang, 1993). The nSCS is located to the west of the warm pool - however the response of the nSCS has not been well documented. In the present study, pronounced responses to ENSO were found. During the observation period, 9 El Nino events (1976, 1982-1983, 1986-1987, 1991, 1993, 1994, 1997, 2002 and 2004) and 4 La Nina events (1981, 1988, 1995 and 1998-1999) occurred (Wang and Gong, 1999; Qin, 2003; Mcphaden, 2004; Levimson, 2005). In general, whenever El Nino/La Nina occurred, SST and $T_{a v}$ was low/high in the nSCS (Fig. 2, Table 4).

In the area southwest of Dongsha Islands, near Station 4 $\left(19-20^{\circ} \mathrm{N}, 116-117^{\circ} \mathrm{E}\right.$, Fig. 1), pronounced responses to ENSO were observed. In general, whenever an El Nino event occurred, $T_{a v}$ and DO were lower, and that the $S_{a v}$, nutrients $\left(\mathrm{PO}_{4}-\mathrm{P}_{a v}, \mathrm{SiO}_{3}-\mathrm{Si}_{a v}\right.$ and DIN), sea surface Chl$a$ were higher (Table 5, Fig. 11). During a La Nina event, contrary, $T_{a v}$ and DO were higher, and that the $S_{a v}$, nutrients $\left(\mathrm{PO}_{4}-\mathrm{P}_{a v}, \mathrm{SiO}_{3}-\mathrm{Si}_{a v}\right.$ and DIN), sea surface Chl- $a$ were lower (Table 5, Fig. 11). The fluctuations of environmental parameters evident corresponded to El Nino/La Nina events. Furthermore, in comparison of the average values of the environmental parameters in summer of El Nino years with those of La Nina years, $\mathrm{T}_{a v}$ and $\mathrm{DO}_{a v}$ were lower by $1.89^{\circ} \mathrm{C}$ and $20.2 \mu \mathrm{mol} \mathrm{L}^{-1}$, respectively; while $S_{a v}$ was higher by
$0.31 \mathrm{psu} ; \mathrm{PO}_{4}-\mathrm{P}_{a v}, \mathrm{SiO}_{3}-\mathrm{Si}_{a v}$ and $\mathrm{DIN}_{a v}$ were higher by $0.15,6.41$ and $3.42 \mu \mathrm{mol} \mathrm{L}^{-1}$, respectively. Surface Chl- $a$ concentration was higher by $0.14 \mathrm{mg} \mathrm{m}^{-3}$, i.e. higher by 1.8 times (Table 5), even higher by 0.83 times than the average value of normal years $(1980,1990,2000,2001$ and 2003, for which mean Chl- $a=0.12 \pm 0.05 \mathrm{mg} \mathrm{m}^{-3}$ ).

According to Takano et al. (1998) and Liao et al. (2006), there is a cyclonic eddy in the sea area around Station 4 (near Dongshan Islands) in summer. Whenever a medium and strong El Nino occurs, the summer monsoon is weak (Zhang et al., 2003; Zhu et al., 2000), which induces strengthened cyclonic eddy, leading to strong upwelling, resulting in low $T_{a v}$ and $\mathrm{DO}_{a v}$, and high $S_{a v}$, nutrients and Chl- $a$ induced by phytoplankton growth. During a La Nina event, the opposite occurs. This is due to ENSO/La Nina events affecting the strength of the summer monsoon related, i.e. both El Nino and La Nina make the anomaly of Walker circulation. During El Nino event, the heat convection of the western Pacific warm pool moves to the central Pacific. In contrast, during La Nina event, the heat convection of the western Pacific warm pool moves back to the western Pacific. That makes the anomaly of Walk circumfluence. Namely, when phase of El Nino (La Nina) fall under the influence of the anomal Walker circulation, subsidence (ascending) air current occur over low latitude and middle latitude of the east Asia. If this subsidence (ascending) air current flow over low latitude occurred in summer, and joined to west-south monsoon, it will result in weaken (strengthen) of the summer monsoon (Wang et al., 2001; Zhang et al., 2003; Zhu et al., 2000). The changes of ecological environment in the sea area around Station 4 in summer respond to ENSO events, namely, respond to the abnormity of summer monsoon.

\subsection{Response of the ecosystem and living resources}

Although the frequency of observation on various biology and fisheries parameters was less than that for physical and chemical parameters which reflected the long term changes in the environmental processes, some responses of the ecosystems to these environmental changes in the nSCS was still evident.

Comparing the biology and fisheries data between the two phases discussed above, the average values of Chl$a$, primary production, phytoplankton abundance, benthos biomass, cephalopod catch and demersal trawl catch increased by $6.4,1.4,2.4,0.7,7.2$ and 2.8 times, respectively during the second phase, except for zooplankton abundance which decreased by about 50\% (Table 6). The decrease in zooplankton abundance may be related to the increase in its predators, such as fish, cephalopods, etc. (Fig. 12). The $R_{x t}$ values of the cephalopod and demersal trawl catches were 0.89 and 0.88 , respectively, and highly significant $(p \leq 0.01)$. Besides, the increase in both the cephalopod and demersal trawl catches partially could be attributed to the improvement of demersal trawl fishing techniques, and also to the increase 
Table 4. Annual mean of SST and $T_{a v}$ along transect N in the nSCS in El Nino and La Nina years during 1976-2004 (unit: ${ }^{\circ} \mathrm{C}$ ).

\begin{tabular}{lcccccccccc}
\hline El Nino Year & 1976 & $1982(1983)$ & $1986(1987)$ & 1991 & 1993 & 1994 & 1997 & 2002 & 2004 & Mean \pm SD $^{\mathrm{a}}$ \\
\hline SST & 23.87 & $25.82(25.09)$ & $25.60(25.73)$ & 25.08 & 25.89 & 26.24 & 25.77 & 26.66 & 26.25 & $25.64 \pm 0.75$ \\
$T_{a v}$ & 21.13 & $21.40(23.40)$ & $23.09(23.32)$ & 21.46 & 21.65 & 21.79 & 22.25 & 22.98 & 22.62 & $22.27 \pm 0.83$ \\
La Nina Year & & 1981 & 1988 & & 1995 & 1998 & 1999 & & & \\
SST & & 25.09 & 25.68 & & 25.74 & 26.61 & 26.21 & & & $25.87 \pm 0.58$ \\
$T_{a v}$ & & 23.28 & 23.72 & & 24.00 & 24.07 & 24.51 & & & $23.92 \pm 0.46$ \\
\hline
\end{tabular}

${ }^{\text {a }}$ Mean \pm SD is the multi-year mean value $\pm(\mathrm{SD})$, standard deviation for the El Nino/La Nina years.
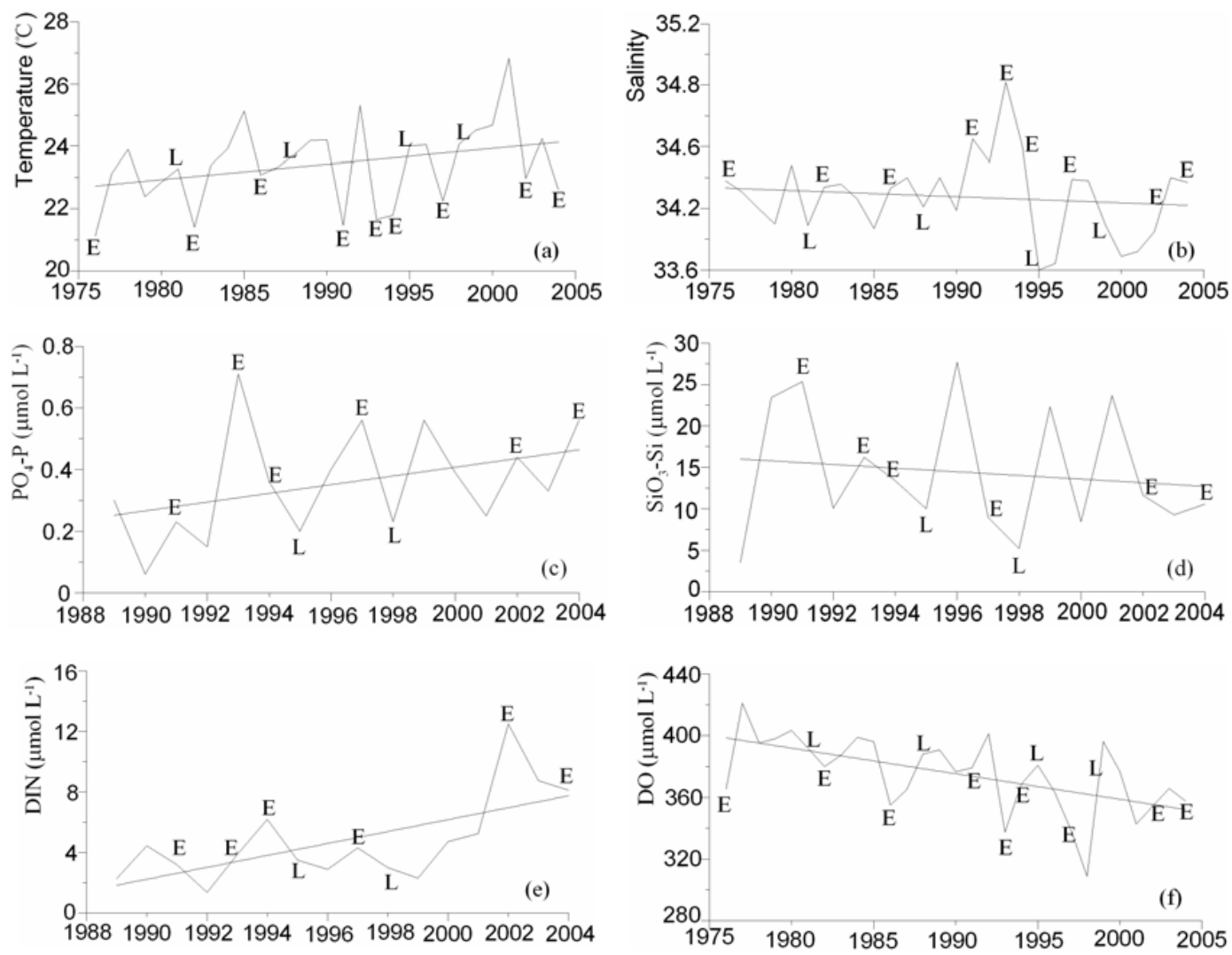

Fig. 11. The interannual changes of the water column average values of the seawater temperature (a), (b) salinity, (c) $\mathrm{PO}_{4}-\mathrm{P},(\mathbf{d}) \mathrm{SiO}{ }_{3}-\mathrm{Si}$, (e) DIN and (f) DO at the Station 4 of the nSCS in summer during the observation period.

in stock and production of low trophic levels, induced by the alleviation in $\mathrm{N}$ limitation in the $\mathrm{nSCS}$.

In addition, after 1997, phosphorus depletion in surface waters during summer coincided with a shift in the dominant species in phytoplankton community from diatoms to dinoflagellates and cyanophytes (Ning et al., 2004). Peng et al. (2006) pointed out that dinoflagellates composed more than $60 \%$ of the total phytoplankton abundance in the HK Southeast Anti-Cyclonic Eddy and Hainan Island East AntiCyclonic Eddy of the nSCS, where P concentration was near detection limit in the summer of 2004.
In second phase our above observations were consistent with the results obtained by the multidisciplinary investigations for assessing the environmental health status and the fisheries environment quality in the nSCS during 1997-2002 (Jia et al., 2005). They reported that both primary production and phytoplankton abundance were relatively high, averaging $409.7 \mathrm{mg} \mathrm{C} \mathrm{m}^{-2} \mathrm{~d}^{-1}$, and $837 \times 10^{3} \mathrm{cell} \mathrm{m}^{-3}$, respectively (according to criterion of grade of primary productivity and diet organism lever of China, Jia et al., 2003). The benthic biomass (averaging $11.3 \mathrm{~g} \mathrm{~m}^{-2}$ ) was at normal levels (the same as above row, Jia et al., 2003). The zooplankton biomass (averaging $22.1 \mathrm{mg} \mathrm{m}^{-3}$ ) was low (the 
Table 5. The mean of the ecological parameter for the water column $(0-200 \mathrm{~m})$ and sea surface Chl- $a$ concentration at Station 4 in summer of El Nino/La Nina years during the study period (units: ${ }^{\circ} \mathrm{C}$ for temperature, psu for salinity, $\mu \mathrm{mol} \mathrm{L}^{-1}$ for $\mathrm{DO}$ and nutrients and $\mathrm{mg} \mathrm{m} \mathrm{m}^{-3}$ for Chl- $a$ ).

\begin{tabular}{|c|c|c|c|c|c|c|c|c|c|c|}
\hline El Nino Year & 1976 & 1982 (1983) & 1986 (1987) & 1991 & 1993 & 1994 & 1997 & 2002 & 2004 & $\operatorname{Mean} \pm \mathrm{SD}^{\mathrm{a}}$ \\
\hline$T_{a v}$ & 21.13 & $21.40(23.40)$ & $23.09(23.32)$ & 21.46 & 21.65 & 21.79 & 22.25 & 22.98 & 22.62 & $22.26 \pm 0.80$ \\
\hline $\mathrm{S}_{a v}$ & 34.18 & $34.14(34.16)$ & $34.13(34.2)$ & 34.45 & 34.82 & 34.41 & 34.19 & 33.85 & 34.17 & $34.25 \pm 0.25$ \\
\hline $\mathrm{DO}_{a v}$ & 365.6 & $380.1(387.3)$ & 355.1 (364.9) & 379.2 & 337.3 & 368.5 & 339.0 & 354.2 & 357.8 & $362.6 \pm 16.0$ \\
\hline $\mathrm{PO}_{4}-\mathrm{P}_{a v}$ & & & & 0.23 & 0.71 & 0.36 & 0.56 & 0.44 & 0.56 & $0.48 \pm 0.17$ \\
\hline $\mathrm{SiO}_{3}-\mathrm{Si}_{a v}$ & & & & 25.36 & 16.22 & 13.38 & 8.96 & 11.65 & 10.56 & $14.36 \pm 5.94$ \\
\hline $\mathrm{DIN}_{a v}$ & & & & 3.20 & 3.85 & 6.19 & 4.29 & 12.51 & 8.12 & $6.36 \pm 3.50$ \\
\hline Chl- $a^{\mathrm{b}}$ & & 0.31 & & & & & & 0.17 & 0.18 & $0.22 \pm 0.08$ \\
\hline La Nina year & 1981 & 1984 & 1988 & & 1995 & 1998 & 1999 & & & \\
\hline$T_{a v}$ & 23.28 & 25.30 & 23.72 & & 24.00 & 24.07 & 24.51 & & & $24.15 \pm 0.70$ \\
\hline $\mathrm{S}_{a v}$ & 33.89 & 34.06 & 34.01 & & 33.60 & 34.18 & 33.90 & & & $33.94 \pm 0.20$ \\
\hline $\mathrm{DO}_{a v}$ & 391.7 & 431.0 & 388.2 & & 380.8 & 308.7 & 396.2 & & & $382.8 \pm 40.3$ \\
\hline $\mathrm{PO}_{4}-\mathrm{P}_{a v}$ & & & & & 0.20 & 0.23 & 0.56 & & & $0.33 \pm 0.20$ \\
\hline $\mathrm{SiO}_{3}-\mathrm{Si}_{a v}$ & & & & & 10.00 & 5.20 & 22.32 & & & $7.95 \pm 12.45$ \\
\hline $\mathrm{DIN}_{a v}$ & & & & & 3.50 & 3.00 & 2.31 & & & $2.94 \pm 5.98$ \\
\hline Chl- $a^{\mathrm{b}}$ & & $0.08,0.06$ & & & & 0.08 & 0.09 & & & $0.08 \pm 0.01$ \\
\hline
\end{tabular}

${ }^{\text {a }}$ Mean \pm SD is the multi-year mean value \pm standard deviation for the El Nino/La Nina years.

b The Chl- $a$ data were derived from SeaWiFS during 1998-2004, from Nimbus-7 CZCS in 1980 and 1984, provided by X. Chen, from The Third Institute of Oceanography, SOA, China for 1982, Fan (1985) and Huang (1992) for 1990, respectively.

Table 6. Comparison of the multi-year mean values of Chl- $a$, primary production (PP), phytoplankton abundance (PA), zooplankton biomass (ZB), benthos biomass (BB), cephalopod catch (CC) and demersal trawl catch (DTC) in the nSCS between two periods, i.e. before and after 1997 (units: $\mathrm{mg} \mathrm{m}^{-3}, \mathrm{mg} \mathrm{C} \mathrm{m}^{-2} \mathrm{~d}^{-1}, \times 10^{3}$ cell $\mathrm{m}^{-3}, \mathrm{mg} \mathrm{m}^{-3}, \mathrm{~g} \mathrm{~m}^{-2}, \times 10^{4} \mathrm{t}$, and $\times 10^{4} \mathrm{t}$, respectively) ${ }^{\mathrm{a}}$.

\begin{tabular}{lll}
\hline Parameter & First phase (data source) & Second phase (data source) \\
\hline Chl- $a$ & $0.29($ Fan 1985) & 2.16 (Cai et al., 2002a; SOAC 2003) $^{\mathrm{b}}$ \\
PP & $185.7($ Fan, 1985) & $442.5($ Ning et al., 2004; Jia et al., 2005; Hao et al., 2007) \\
PA & $161.5($ Lin, 1985) & $542.7(\text { Jia et al., 2005) })^{\mathrm{b}}$ \\
ZB & $44.5($ Zhang, 1984; Chen, 1985; Qian et al., 1990a, b; & 22.05 (Jia et al., 2005) $^{\mathrm{d}}$ \\
& Huang et al., 1990; Chen, 1992) & \\
BB & 6.6 (Shen, 1985) & $11.3($ Jia et al., 2005) \\
CC & $1.2($ Guo and Chen, 2000) & $9.8($ Guo and Chen, 2000) \\
DTC & $89.0($ Guo and Chen, 2000) & $334.8($ Guo and Chen, 2000) \\
\hline
\end{tabular}

a The data listed in the Table are the mean of the water column of the multi-year average for each parameter from different sources, except for BB, CC and DTC which are only treated by the multi-year average;

$\mathrm{b}$ The data were provided by Chen, $\mathrm{X}$. from The Third Institute of Oceanography, SOA, China;

c The data was from the National Science Foundation of China (NSFC) project under the contract No. 90211021;

d The data from Jia et al. (2005) are the annual mean of the multi-year mean for each season during 1997-2002.

same as above row, Jia et al., 2003). And nutrients were also low, i.e. the mean values of $\mathrm{PO}_{4}-\mathrm{P}=0.28 \mu \mathrm{mol} \mathrm{L}^{-1}$ and DIN $=3.63 \mu \mathrm{mol} \mathrm{L}^{-1}$ (according to criterion of Nutrition grade of sea water of China, Jia et al., 2003). The nutrients values (Jia et al., 2005, nutrients) are much lower than those we observed and the average index of ecological environment quality of fishing ground is 0.58 , indicating it was in good condition (Jia et al., 2005).
The first phase (before 1997) represents the initial status of the biology and fisheries during the study period, and the second phase (after 1997) represents the response of the ecosystem to the changed environment, particularly since 1998, when the occurrence of $\mathrm{N}$ limitation was significantly alleviated. These ecosystem responses discussed above were clearly the result of environmental changes induced by not only climate change, but also anthropogenic activities. 

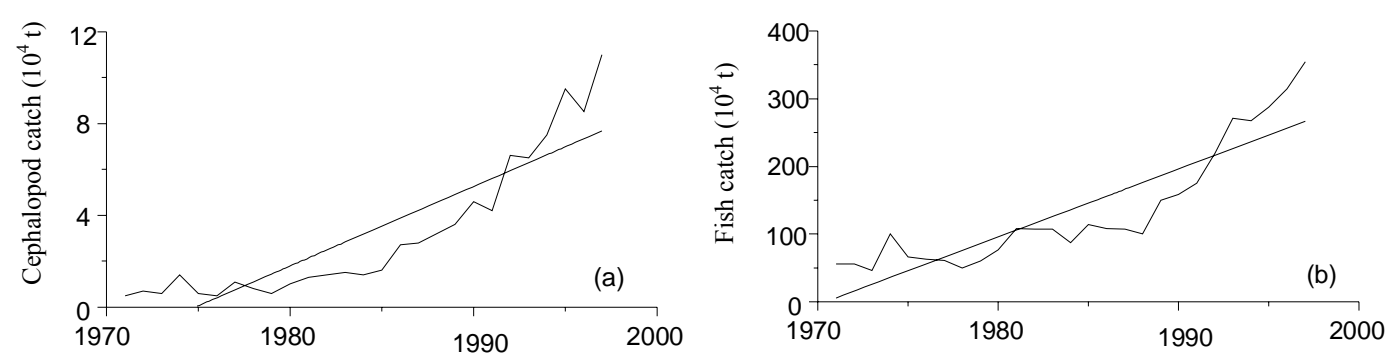

Fig. 12. Variation trends in the catches of cephalopod and fishes of the nSCS. (a) Catches of cephalopod; (b) Catches of fishes (Data from Guo and Chen, 2000).

\section{Conclusion}

The fluctuations in environmental parameters in the nSCS during 1976-2004 displayed different patterns, i.e. temperature (SST and $T_{a v}$ ), salinity $\left(\mathrm{S}_{a v}\right.$ and $\mathrm{S}_{200}$ ), dissolved inorganic nitrogen (DIN) and N:P annual rates increased, while DO, P, Si, Si:N, SSS and $T_{200}$ annual rates decreased. The climate trend coefficients, $R_{x t}$ of these time series were all over $0.38(n=29)$ or $0.50(n=16)$, and highly significant $(p \leq 0.05)$, except for the time series of P and Si.

The increasing trends in SST and $T_{a v}$ were consistent with the rise of the mean air temperature (AT) in the Northern Hemisphere and southern China. The increase in SST and $T_{a v}$ and decrease in SSS in the nSCS led to strengthening of the thermocline and halocline, less mixing of deep water to the surface and thus a decrease in the P supply from deep waters. The increasing trend in DIN may have been influenced by the Pearl River discharge, and atmospheric dry and wet deposition, (which are related to anthropogenic activities), coastal upwelling and cyclonic eddies. The nSCS always experienced limitation of $\mathrm{N}$ before 1997, but the situation in the upper layer sea water has been mitigated since 1998, due to the increase in $\mathrm{N}$ concentration and decrease in $\mathrm{P}$, which resulted in not only the positive trends in $\mathrm{N}: \mathrm{P}$ ratios which are now close to the Redfield ratio, but also the decreasing trend in Si:N ratios, indicating of potential P limitation. The decrease in DO concentration may be linked to the increase in seawater temperature and the increase in the concentration of organic matter inputs mainly from the Pearl River and phytoplankton blooms, particularly since the 1990s. Chlorophyll- $a$, primary production, phytoplankton abundance, benthos biomass, cephalopod catch and demersal trawl catch have increased, and zooplankton abundance decreased. These ecosystem responses resulted from environmental changes were induced by not only climate change, but also anthropogenic activities. After 1998, phosphorus depletion in upper layer may be associated with a shift from diatoms to dinoflagellates and cyanophytes domination.

Pronounced responses of the environmental parameters to ENSO were observed. The effects of climate change on the nSCS were mainly through changes in monsoon and its causative links, monsoon - circulation - nutrients - primary production.

It must be pointed out that although the data set we adopted in the present analysis is large and from various sources. As such the quality of data might vary throughout the long period of observation. But these data were valuable for studying the long term changes in environmental conditions and the responses of the ecosystem in this region. And using these data we can still find and understand some regulations on the response of the ecosystems to the environmental changes in the SCS. This regional response of SCS to global climate change was investigated the first which is far from well understood. The evolving nutrient environment may be related to the observed ecosystem changes in the nSCS such as increase in biological productivity. More long-time series observations on the structure and function of ecosystems and the relationships with environmental changes are needed in the SCS in the future.

Acknowledgements. This study was supported by the National Science Foundation of China (NSFC) key projects under the contracts No. 90211021 and No. 90711006. The authors would like to thank the Information Center of SOA for providing the environmental data, and to Paul Harrison for his significant comments.

Edited by: M. Dai

\section{References}

Cai, Y., Ning, X., and Liu, C.: Distribution characteristics of sizefractionated chlorophyll $a$ and productivity of phytoplankton in the northern South China Sea and Beibu Gulf during August 1999, Studia Marina Sinica, 44, 11-21, 2002a (in Chinese).

Cai, Y., Ning, X., and Liu, Z.: Studies on primary production and new production of the Zhujiang Estuary, China, Acta Oceanol. Sinica, 24, 101-111, 2002b (in Chinese).

Cai, Y., Ning, X., Liu, C., and Hao, Q.: Distribution pattern of photosynthetic picoplankton and heterotrophic bacteria in the northern South China Sea, J. Integrative Plant Biol., 49, 282-298, 2007.

Chai, F., Xue, H., and Shi, M.: Formation and distribution of upwelling and downwelling in the South China Sea, Oceanogr. in China, 13, 105-116, 2001 (in Chinese). 
Chen, L., Zhu, W., Wang, W., Zhou, X., and Li, W.: Studies on climate change in China in recent 45 years, Acta Meteorol. Sinica, 56, 257-271, 1998 (in Chinese).

Chen, Q.: Report on the multidisciplinary investigation of the South China Sea (II), China Science Press, Beijing, 432 pp, 1985 (in Chinese).

Chen, Q.: Compiling of the Information on Resources of the Seas and Islands in Guangdong Province, Guangdong People Press, Guangzhou, 622 pp, 1992 (in Chinese).

Chen, S. and Ma, J.: The analytical methods and its application of the disposal of marine data, China Ocean Press, Beijing, 660 pp, 1991 (in Chinese).

Chen, T., Qian, G., and Zeng, X.: Trends of the changes in air temperature in Hong Kong, Macao and Guangzhou during 20th century. Studies and Developments in the South China Sea, 1, 1217, 1999.

Chen, X., Qi, Y., and Wang, W.: Seasonal and annual changes in the characteristics of mesoscale eddies in the South China Sea, J. Tropical Oceanogr., 24, 51-57, 2005 (in Chinese).

Chu, S. P.: Experimental studies on the environmental factors influencing the growth of phytoplankton, Con. Fish. Res. Inst. Dept. Fish Nat. Univ. Shantung, I, 37-52, 1949.

Fan, J.: Report on the multidisciplinary investigation of the South China Sea (II), China Sci. Press, Beijing, 432 pp, 1985 (in Chinese).

Fang, G., Fang, W., Fang, Y., and Wang, K.: A survey of studies on the South China Sea upper ocean circulation, Acta Oceanogr. Taiwanica, 37, 1-16, 1998.

Fu, Q., Celeste, M., Johanson, J. M. W., and Thomas, R.: Enhanced mid-latitude tropospheric warming in satellite measurements, Science, 312, 1179, 2006.

Gong, G. C., Liu, K. K., Liu, C. T., and Pai, S. C.: Chemical hydrography of the South China Sea and a comparison with the West Philippine Sea, Terr. Atmos. Oceanic Sci., 3, 587-602, 1992.

Guan, W., Wong, L., and Xu, D.: Modeling nitrogen and phosphorus cycles and dissolved oxygen in the Zhujiang River Estuary, Part II. Modeling results, Acta Oceanol. Sinica, 25, 61-68, 2003 (in Chinese).

Guo, J. and Chen, P.: Study on exploitation of cephalopod stock in the South China Sea, J. Tropic Oceanogr., 19, 51-58, 2000 (in Chinese).

Han, W., Wu, L., and Lin, H.: Preliminary research on cultivating hydrochemistry of waters off Hong Kong, Mar. Sci. Bull., 9, 3744, 1990 (in Chinese).

Han, W.: Chemistry Oceanography of the South China Sea, China Science Press, 289 pp, 1998 (in Chinese).

Hao, Q., Ning, X., Liu, Y., Cai, Y., and Le, F.: Satellite and situ observations of primary production in the northern South China, Acta Oceanol. Sinica, 29, 58-68, 2007 (in Chinese).

Harvey, H. W.: Chemistry and Fertility of Seawater, Cambridge Univ. Press, Cambridge, 234 pp, 1957.

He, Y. Z., Cheng, C., and Guan, C.: Relationship between long-term changes of summer rainfall in the northern China and sea surface temperature over the South China Sea, J. Tropical Oceanogr., 22, 1-8, 2003 (in Chinese).

He, G., Yuan, G., and Li, F.: Effect of economic development on water quality in the Pearl Estuary, Mar. Environ. Sci., 23, 50-52, 2004 (in Chinese).

Hong, W., Hu, Q., Wu, Y., and Zhang, S.: Marine phytoplankton,
China Agriculture Press, Beijing, 299 pp, 1983 (in Chinese).

Houghton, J. T., Filho, L. G. M., Callander, B. A., Harris, N., Kattenberg, A., and Maskell, K.: Climate change in 1995: the science of climate change, Contribution of Working Group I to the Second Assessment Report of the Intergovernmental Panel on Climate Change, Cambridge University Press, Cambridge, 572 pp, 1996.

Holm-Hansen, O., Lorenzen, C. J., Holmes, R. W., and Strickland, J. D. H.: Fluorometric determination of chlorophyll, J. Cons. Perm. Int. Explor. Mer, 30, 3-15, 1965.

Hu, M., Yang, Y., Xu, C., and Halisen, J. P.: Limitation of phosphate on phytoplankton growth in the Changjiang River estuary, Acta Oceanol. Sinica, 11, 439-443, 1989 (in Chinese).

Huang, L.: Vertical variations of chlorophyll $a$ and fluorescence values in different areas of the South China Sea, J. Tropical Oceanogr., 11, 89-95, 1992 (in Chinese).

Huang, Y., Qian, Q., Ou, Q., Huang, Y., and Liu, J.: Investigation of zooplankton in the around area of Hainan-Island of the South China Sea, Acta Ji-Nan University, 6, 74-80, 1990 (in Chinese).

Hutchins, D. A. and Bruland, K. W.: Iron-limited diatom growth and $\mathrm{Si}: \mathrm{N}$ uptake in a coastal upwelling regime, Nature, 393, 561-564, 1998.

Jia, X., Li, C., Gan, J., Lin, Q., Cai, W., and Wang, Z.: Diagnosis and assessment on the health status and quality of the fisheries eco-environment of the northern South China Sea, J. Fish. Sci. China, 12, 757-765, 2005 (in Chinese)

Jia, X., Du, F., Lin, Q., Li, C., and Cai, W.: A study on comprehensive assessment method of ecological environment quality of marine fishing ground, J. Fish. Sci. China, 10, 160-164, 2003 (in Chinese).

Jiang, J. and Yao, R.: Effects of nitrogen to phosphorus ratio on growth of Dunaliella salina and accumulation of glycerol and pigments, J. Tropical Oceanogr., 18, 68-72, 1999 (in Chinese).

Justic, D., Rabalais, N. N., and Turner, R. E.: Changes in nutrient structure of river-dominated coastal waters: Stoichiometric nutrient balance and its consequences, Estuarine, Coast. Shelf Sci., 40, 339-356, 1995.

Lei, Y., Yang, X., Hu, Q., Luo, Z., and Yang, G.: Hydraulic geometry features and channel evolution of the Dong-Ping waterway in last decades, Tropical Geography, 23, 204-208, 2003 (in Chinese).

Levimson, D. H.: State of the Climate in 2004, B. Am. Meteorol. Soc., 6, 17-18, 2005.

Li, Y., Cai, W., Li, L., and Xu, D.: Seasonal and interannual variabilities of mesoscale eddies in the northeastern South China Sea, J. Tropical Oceanogr., 22, 1-8, 2003 (in Chinese).

Li, Z. and Chen, K.: Seawater quality and its change trends along the coast of the northern South China Sea, Res. Develop. South China Sea, 1, 15-23, 1998 (in Chinese).

Liao, G., Yuan, C., and Wang, Z.: Three dimensional structure of the circulation in the South China Sea during of 1998, Acta Oceanol. Sinica, 28, 15-25, 2006 (in Chinese).

Lin, C., Ning, X., Su, J., Lin, Y., and Xu, B.: Environmental changes and the responses of the ecosystems of the Yellow Sea during 1976-2000, J. Mar. Syst., 55, 223-234, 2005.

Lin, C., Su, J., Xu, B., and Tang, Q.: Long-term variations of temperature and salinity of the Bohai Sea and their influence on its ecosystem, Prog. Oceanogr., 49, 9-17, 2001.

Lin, H. and Han, W.: Study on the dissolved oxygen flux in the 
South China Sea, Chin. J. Oceanol. Limnol., 29, 61-66, 1998 (in Chinese).

Lin, Y.: Report of the synthetic investigation of the South China Sea (II), China Sci. Press, Beijing, 432 pp, 1985 (in Chinese).

Lin, Y., Su, J., Hu, C., Zhang, M., Li, Y., Guan, W., and Chen, J.: $\mathrm{N}$ and $\mathrm{P}$ in water of the Zhujiang River estuary in summer, Acta Oceanol. Sinica, 26, 63-73, 2004 (in Chinese).

Liu, K. K., Chao, S. Y., Shaw, P. T., Gong, G. C., Chen, C. C., and Tang, T. Y.: Monsoon-forced chlorophyll distribution and primary production in the South China Sea: observations and a numerical study, Deep-Sea Res. I, 49, 1387-1412, 2002.

Liu, K. K., Kao, S. J., Hu, H. C., Chou, W. C., Hung, G. W., and Tseng, C. M.: Carbon isotopic composition of suspended and sinking particulate organic matter in the northern South China Sea - from production to deposition, Deep Sea Res. Part II, 54, 1504-1527, 2007.

Martin, H. and Arun, K.: Perfect ocean for drought, Science, 299, 691-696, 2003.

Mcphaden, M. J.: Evolution of the 2002-2003 E1 Nino, B. Am. Meteorol. Soc., 5, 677-695, 2004.

NBTS (National Bureau for Technique Supervision): Marine Biology Survey, In: Specifications for Oceanographic Survey, GB 12763.6-91, 104 pp, 1991 (in Chinese).

Ning, X., Chai, F., Xue, H., Cai, Y., Liu, C., and Shi, J.: Physicalbiological oceanographic coupling influencing phytoplankton and primary production in the South China Sea, J. Geophys. Res., 109(C10), C10005, doi:10.1029/2004JC002365, 2004.

Nitani, H.: Beginning of the Kuroshio, in: Kuroshio, edited by: Stommel, H., and Yoshida, K., Univ. Wash. Press, Seattle, 517 pp, 1972.

Peng, Y., Chen, L., and Chen, H.: Relationship between dissolved oxygen and nutrients in the Pearl River estuary, J. Tropical Oceanogr., 13, 96-100, 1994 (in Chinese).

Peng, X., Ning, X., Sun, J., and Le, F.: Responses of phytoplankton growth on nutrient enrichments in the northern South China Sea, Acta Ecol. Sinica, 22, 3959-3968, 2006 (in Chinese).

Qian, H., Huang, Y., Ou, J., Huang, Y. L., Liu, J., and Huang, Y.: Investigation of zooplankton in the around area of the HuangIsland in the South China Sea, Acta Ji-Nan. Univ., 6, 81-84, 1990a (in Chinese).

Qian, H., Huang, Y., Ou, J., Huang, Y. L., Liu, J., and Yu, W.: Investigation of zooplankton in the northeastern area of the northern South China Sea, Acta Ji-Nan. Univ., 6, 70-73, 1990b (in Chinese).

Qin, D.: El Nino Phenomena, Meteorology Press, Beijing, 180 pp, 2003 (in Chinese).

Qiu, Y., Wang, S., and Zhu, L.: Variation trend of nutrient and chlorophyll $a$ contents and their effects on eco-environment in Daya Bay, J. Oceanogr. in Taiwan Strait, 24, 131-139, 2005 (in Chinese).

Richardson, K.: Harmful or exceptional phytoplankton blooms in the marine ecosystem, Adv. Mar. Biol., 31, 301-385, 1997.

Sadler, J., Lander, C. M. A., and Oda, L. K.: Tropical Marine Climate Atlas, I, Indian Ocean and Atlantic Ocean, Univ Hawaii, Honolulu, 100 pp, 1985.

Seitzinger, S. P., Kroeze, C., Bouwman, A. F., Caraco, N., Dentener, F., and Styles, R. V.: Global patterns of dissolved inorganic and particulate nitrogen inputs to coastal systems: recent conditions and future projections, Estuaries, 25(4), 640-655, 2002.
Shaw, P. T.: Seasonal variation of the intrusion of the Philippine Sea water into the South China Sea, J. Geophys. Res., 96, 821-827, 1991.

Shen, S.: Report of the multidisciplinary investigation of the South China Sea (II), China Sci. Press, Beijing, 403-424, 1985 (in Chinese).

Shi, N., Chen, J., and Tu, Q.: 4-phase climate change feature in the last 100 years over China, Acta Meteorol. Sinica, 53, 431-439, 1995 (in Chinese).

Shi, P., Du, Y., Wang, D., and Gan, Z.: Annual cycle of mixed layer in the South China Sea, J. Tropical Oceanogr., 20, 10-17, 2001 (in Chinese)

SOAC (State Oceanic Administration of China): Specification for Oceanogr. Survey, Beijing, 550 pp, 1975 (in Chinese).

SOAC: Status of the Environ. Quality of the China Sea in the End of $20^{\text {th }}$ Century, SOAC, $167 \mathrm{pp}, 2001$ (in Chinese).

SOAC: Seawater Quality Results of Survey, SOAC, 15 pp, 2000 (in Chinese).

SOAC: Seawater Quality Results of Survey, SOAC, 30 pp, 2001 (in Chinese).

SOAC: Seawater Quality Results of Survey, SOAC, 20 pp, 2002 (in Chinese)

SOAC: Seawater Quality Results of Survey, SOAC, 22 pp, 2003 (in Chinese)

SOAC: Seawater Quality Results of Survey, SOAC, 23 pp, 2004 (in Chinese).

Sournia, A.: Phytoplankton Manual, UNESCO, Paris, 337 pp, 1978.

Steemann Nielson, E.: The use of radioactive carbon $\left({ }^{14} \mathrm{C}\right)$ for measuring organic production in the sea, J. Cons. Int. Expor. Mer., $18,117-140,1952$.

Strickland, J. D. H. and Parsons, T. R.: A practical handbook of seawater analysis, Bull. Fish. Res. Bd. Can., 167, 310 pp, 1972.

Su, J.: Circulation dynamics of the China Sea: north of $18^{\circ} \mathrm{N}$, in: The Sea, 11, The Global Coastal Ocean: Regional Studies and Syntheses, edited by: Robinson, A. R. and Brink K., John Wiley Press, 506 pp, 1998.

Takano, K., Akira, H., and Takaya, N.: A numerical simulation of the circulation in the South China Sea - preliminary results, Acta Oceanogr. Taiwanica, 37, 165-186, 1998.

Takeuchi, N.: Auspice of ENSO, Physical geography research report of Hokkaido University, 492, 381-386, 1987 (in Japanese).

Tang, D., Wang, S., and Di, B.: Harmful algal blooms in the coastal waters of the South China Sea. Marine Science and Technology in Asia, June 11-15, PACON, 2006.

Wang, D. and Peng, Y.: Nutrient elements of the Zhujiang (Pearl River) estuary waters, China, in: Biogeochemistry Study of China Major River Estuaries, edited by Zhang, J., China Ocean Press, Beijing, 241 pp, 1996 (in Chinese).

Wang, S. and Gong, D.: ENSO events and their intensity during the past century, Meteorology, 25(1), 9-14, 1999 (in Chinese).

Wang, W., Wang, D., and Shi, P.: Annual and interannual variations of large-scale dynamic field in South China Sea, J. Trop. Oceanogr., 20(1), 61-68, 2001 (in Chinese).

Wei, M., Lai, T., and He, B.: Changing trends of the chemical items in Qinzhou Bay during the last twenty years: Nutrient condition., Marine Environ. Sci., 21, 49-52, 2002 (in Chinese).

Wei, M, Lai, T, and He, B.: Change trend of nutrient conditions and influencing factors during flood and dry seasons in Qinzhou Bay, 
J. Tropical Oceanogr., 22, 16-21, 2003 (in Chinese).

White, B. B., Meyes, G. A., and Songu, Y. J. R.: Short-term climatic variability in the thermal structure of the Pacific Ocean during 1979-1982, J. Phys. Oceanogr., 15, 917-935, 1985.

Wolfe, D. A. and Schelske, C. L.: Liquid scintillation and geiger counting efficiencies for carbon-14 incorporated by marine phytoplankton in productivity measurements, ICES J. Mar. Sci., 31, 31-37, 1967.

Wyrtki, K,: Physical oceanography of the southeast Asia waters, in Scientific Results of Marine Investigations of the South China Sea and the Gulf of Thailand, NAGA Rep, Scripps Inst Oceanogr., Lajolla, Calif., 2, 1-195, 1961.

Xie, Z. and Zhang, Y.: Review of the Pearl River flood calamity, The Pearl River, 4, 13-16, 2003 (in Chinese).

Xu, J., Xue, H., Shi, M., and Liu, Z.: Observation and study of the circulation and mesoscale eddies in the upper layer of the South China Sea in summer of 1998, in: Oceanogr. in China, China Ocean Press, Beijing, edited by: Xue, H., Chai, F., and Xu, J., 13, 178-187, 2001.

Xu, J., Yin, K., He, L., Yuan, X., Ho, A. Y. T., and Harrison, P. J.: Phosphorus limitation in the northern South China Sea during late summer: influence of the Pearl River, Deep-Sea Res. I, 55(10), 1330-1342, 2008.

Xue, H., Chai, F., Pettigrew, N., Xu, D., Shi, M., and Xu, J.: Kuroshio intrusion and the circulation in the South China Sea, J. Geophys. Res., 109(C2), C02217, doi:10.1029/2002JC001724, 2004.

Xue, H., Chai, F., Xu, D., and Shi, M.: Characteristics and seasonal variation of the coastal currents in the South China Sea, Oceanogr. China, 13, 64-73, 2001a (in Chinese).

Xue, H., Chai, F., Wong, L., and Chen, J.: Zhujiang River estuarine circulation model, Oceanogr. China, 13, 138-151, 2001b (in Chinese).

Yang, H. and Liu, Q.: Seasonal feature of temperature distribution in the upper layer of the South China Sea, Chin. J. Oceanol. Limnol., 29, 501-507, 1998 (in Chinese).

Yin, K. D., Qian, P. Y., Wu, M. C. S., Chen, J. C., Huang, L., Song, X., and Jian, W.: Shift from P to N limitation of phytoplankton growth across the Pearl River estuarine plume during summer, Mar. Ecol. Prog. Ser., 221, 17-28, 2001.
Yuan, S. and Deng, J.: Thermal-salinity structure in the northern South China Sea, I, Study and Development of the South China Sea, 2, 23-27, 1997a (in Chinese).

Yuan, S. and Deng, J.: Thermal-salinity structure in the northern South China Sea, II, Study and Development of the South China Sea, 3, 19-24, 1997b (in Chinese).

Yuan, S. and Deng, J.: Thermal-salinity structure in the northern South China Sea, III, Study and Development of the South China Sea, 2, 28-36, 1998 (in Chinese).

Zeng, Q., Li, R., and Ji, Z.: Computation of monthly average current, Atmosp. Sci., 13, 127-138, 1989.

Zhai, P. and Ren, F.: On changes of maximum and minimum temperature in China over the recent 40 years, Acta Meteorol. Sinica, 55, 418-429, 1997 (in Chinese).

Zhang, Q. and Huang, R. H.: The space-time character of the development of ENSO events, Chin. J. Atmos. Sci., 17, 395-402, 1993 (in Chinese).

Zhang, Q., Tao, S., and Chen, L.: The interannual variability of East Asian summer indices and its association with the pattern of general circulation over East Asia, Acta Meteor. Sinica, 61, 559-567, 2003 (in Chinese).

Zhang, S.: Ecological study of the planktonic copepoda of the South China Sea, J. Tropical Oceanogr. 3, 46-55, 1984 (in Chinese).

Zhang, J. L., Yu, Z., and Zhang, J.: Wet and dry deposition and its influence on marine ecosystem, Mar. Environ. Sci., 18, 70-76, 1999 (in Chinese).

Zhao, W., Jiao, N., and Zhao, Z.: Distribution and variation of nutrients in aquaculture waters of the Yantai Sishili Bay, Mar. Sci., 4, 31-34, 2000 (in Chinese).

Zhao, H., Tang, D., and Wang, S.: Spatial distribution of chlorophyll $a$ concentration in summer in western South China Sea and its response to oceanographic environmental factors, J. Tropical Oceanogr., 24, 31-37, 2005 (in Chinese).

Zhu, C., He, J., and Wu, G.: East Asian monsoon index and its interannual relationship with large scale thermal dynamic circulation, Acta Meteor. Sinica, 58, 391-401, 2000 (in Chinese).

Zou, J., Dong, L., and Qin, B.: Preliminary analysis of the eutrophication and red tide in the Bohai Sea, Mar. Environ. Sci., 2, 42-54, 1983 (in Chinese). 